IAB-DISCUSSION PAPER

5|2021 Temporary overpessimism: Job loss expectations following a large negative employment shock

Julian Emmler, Bernd Fitzenberger 


\section{Temporary overpessimism: Job loss expectations following a large negative employment shock}

Julian Emmler (Humboldt University Berlin),

Bernd Fitzenberger (IAB, Friedrich-Alexander University Erlangen-Nürnberg, Institute for Fiscal Studies, Center for Economc Studies-ifo, Institute of Labor Economics (IZA), Research Centre for Education and Labor Market (ROA))

Mit der Reihe „IAB-Discussion Paper“ will das Forschungsinstitut der Bundesagentur für Arbeit den Dialog mit der externen Wissenschaft intensivieren. Durch die rasche Verbreitung von Forschungsergebnissen über das Internet soll noch vor Drucklegung Kritik angeregt und Qualität gesichert werden.

The "IAB-Discussion Paper" is published by the research institute of the German Federal Employment Agency in order to intensify the dialogue with the scientific community. The prompt publication of the latest research results via the internet intends to stimulate criticism and to ensure research quality at an early stage before printing. 


\section{Contents}

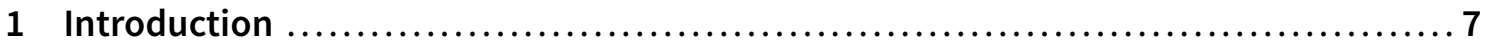

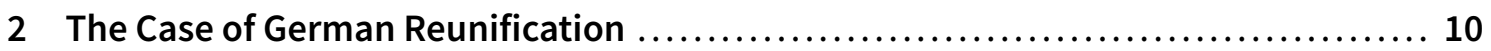

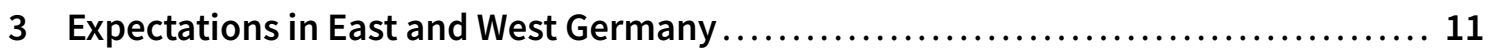

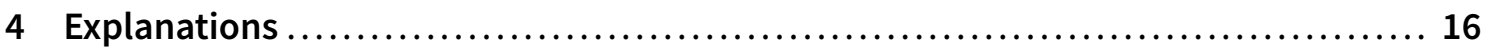

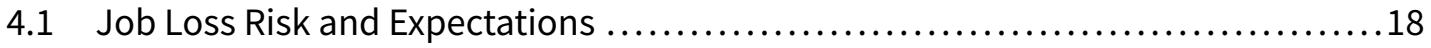

4.2 Effects of Stabilizing Economic Conditions................................. 19

4.3 Effects of Changing Interpretations ........................................ 25

4.4 Convergence to West Germany .......................................29

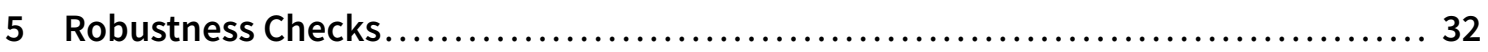

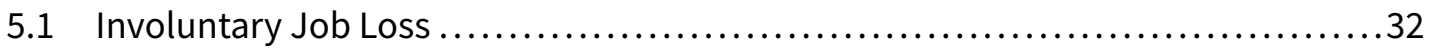

5.2 Additional Outcomes.............................................. 33

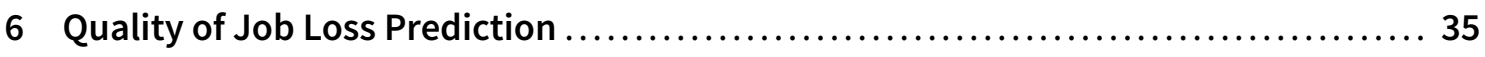

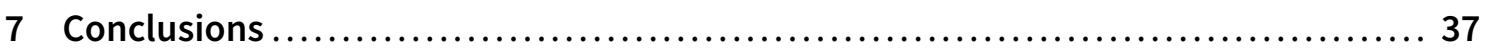

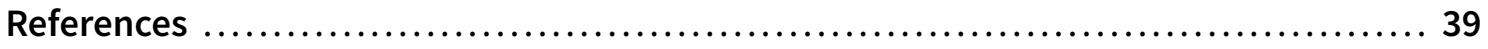

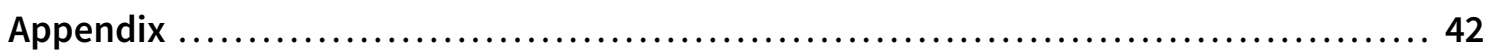

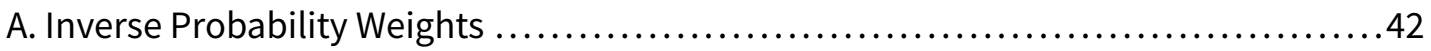

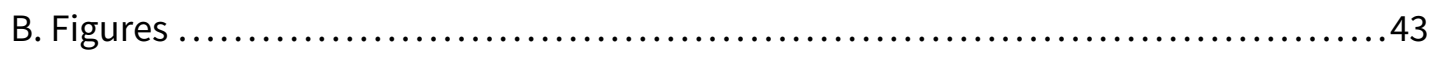

C. Tables .............................................................. 47 


\section{List of Figures}

Figure 1: Shares of Job Loss Expectations and Realized Unemployment ...............12

Figure 2: Accuracy of Job Loss Expectations..................................... 14

Figure 3: Shares of Expectation-Realization Pairs ................................ 15

Figure 4: Realized Unemployment Conditional on Job Loss Expectations................ 16

Figure 5: Job Loss Risk and Expectation-Realization Pairs East Germany................ 18

Figure 6: Job Loss Risk and Expectation-Realization Pairs West Germany ................19

Figure 7: Predictive Power of Changes in Signals for the Share of Job Loss Expecta-

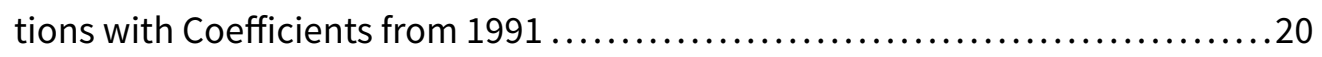

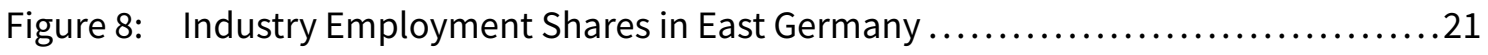

Figure 9: Expected and Past Changes in Firm Employment ...........................22

Figure 10: Predictive Power for the Share of Job Loss Expectations fixing Industry Affiliation or Past or Expected Changes in Firm Employment..................23

Figure 11: Predictive Power of Changes in Signals for the Share of Job Loss Expecta-

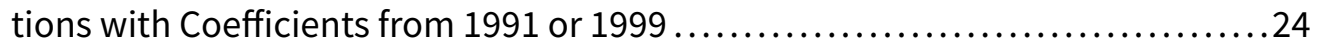

Figure 12: Differences in Signals and Coefficients in East and West Germany . .............30

Figure 13: Differences in Shares of Expected and Past Firm Employment East-West 1991 and 1999

Figure 14: Difference in Shares of Accurate expectations East/West in 1991/99 by Expected Changes in Firm Employment

Figure 15: Realized Unemployment Conditional on Job Loss Expectations after Reweighting

Figure 16: Realized Unemployment through Lay-offs Conditional on Job Loss Expectations37

Figure 17: Shares and Actual Unemployment for Disaggregated Job Loss Expectation Indicator .....................................................43

Figure 18: Predictive Power of Changes in Endowments Across Different Samples ........44

Figure 19: Predictive Power of Changes in Endowments for Job Loss Expectations for different Reference Years ...........................................44

Figure 20: Predictive Power of Changes in Endowments without Exp. Changes in Firm Employment ...................................................46

\section{List of Tables}

Table 1: Determinants of Expectation, Unemployment and Accurate Expectations in East Germany in 1991 and 1999 
Table 2: Determinants of Correct Work, Correct Unemployment, Pessimism and Optimism in 1991 and 1999 in East Germany ..................................28

Table 3: Job Loss Expectations and Changes in Prevalence over Time for Different Types of Job Loss ...........................................................

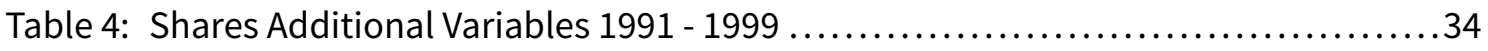

Table 5: Confusion Matrix ..................................................... 47

Table 6: Determinants of Job Loss Expectations, Unemployment and Accurate Expec-

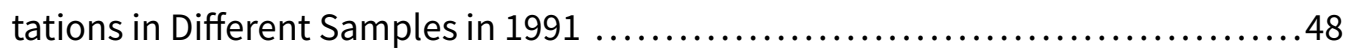

Table 7: Determinants of Job Loss Expectations for all Years .........................49

Table 8: Average Marginal Effects Based on 1991 Coefficients.......................... 50

Table 9: Determinants of Expectations, Unemployment and Accurate Expectations in East Germany without Expected Firm Employment ........................ 51 


\section{Abstract}

Job loss expectations were widespread among workers in East Germany after reunification with West Germany. Though experiencing a large negative employment shock, East German workers were still overpessimistic immediately after reunification with respect to their job risk. Over time, job loss expectations fell and converged to West German levels, which was driven by a stabilizing economic environment and by an adaptation of the interpretation of economic signals with workers learning to distinguish individual risk from firm level risk. In fact, conditional on actual job loss risk, East German workers quickly caught up to West Germans regarding the accuracy of job loss expectations.

\section{Zusammenfassung}

In den Jahren nach den Wiedervereinigung mit Westdeutschland erwartete ein großer Anteil der Ostdeutschen Arbeitnehmer ihren Job zu verlieren. Zwar führte der Wiedervereinigungsschock zu einem substantiell erhöhten Risiko des Arbeitsplatzverlusts in Ost- im Vergleich zu Westdeutschland, die Erwartungen der Ostdeutschen Arbeitnehmer waren jedoch noch negativer und somit zu pessimistisch. Im Laufe der Zeit fiel jedoch die Zahl der erwarteten Arbeitsplatzverluste und konvergierte zum Westdeutschen Niveau, getrieben zum einen durch die sich stabilisierende wirtschaftliche Lage in Ostdeutschland und zum anderen durch einen Lernprozess der Arbeiter im Bezug auf die Trennung von individuellem und firmenspezifischen Risiko. Bedingt auf das wirkliche Risiko den Job zu verlieren schlossen Ostdeutsche Arbeitnehmer schnell zu Westdeutschen Arbeitnehmern auf.

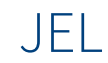

D84, J64, J63, P20

\section{Keywords}

job loss, expectations, transition economies

\section{Acknowledgments}

We thank Alexandra Spitz-Oener as well as audiences in the 'Rationality and Competition' (CRC/TRR 190) workshops and a seminar at IAB for helpful comments. We acknowledge financial support by the Deutsche Forschungsgemeinschaft (DFG) through CRC/TRR 190 'Rationality and Competition', Project A07 'Obstacles to convergence in regional development: Behavioral explanations'. 


\section{Introduction}

Job loss expectations, describing the perceived likelihood of job loss in the near future, are shown to have adverse effects on many labor and non-labor market outcomes and on workers' behavior. Bohle/Quinlan/Mayhew (2001), Knabe/Rätzel (2010), and Green (2011) report a detrimental effect of job loss expectations on well-being and health measures. ${ }^{1}$ Despite this strong evidence, little is known about the formation of job loss expectations at the individual level. In particular, what are the drivers of changes in job loss expectations over time and how do workers' job loss expectations respond to economic shocks? In contrast, there exists a large literature in macroeconomics investigating the formation of expectations (typical applications involve inflation expectations or stock value forecasts). A recent study by Kučinskas/ Peters (2018) analyzes the response of expectations to shocks over time focussing on patterns of under- or overreaction. The review by Coibion/Gorodnichenko/Kamdar (2018) discussing different approaches for expectation formation in the macroeconomic literature.

Our study presents novel empirical evidence at the individual level showing an immediate overshooting of job loss expectations in response to a large negative employment shock as well as a large downward adjustment over time, as the impact of the initial shock fades out. Similarly, Linz/Semykina (2008) show that post-Soviet Russia also experienced high levels of job loss expectations in the early transition period and a strong fall afterwards. To the best of our knowledge, our paper is the first that analyzes the drivers of changes in the prevalence and accuracy of job loss expectations over time.

Our show case is East Germany in the aftermath of reunification. We document a very high initial level of job loss expectations in excess of actual job loss risk (overreaction) but a subsequent strong decline in job loss expectations (convergence to West German levels). We focus on two explanatory factors. On the one hand, changes in the economic environment, which constitute changes in economic signals, lead a worker to update her job loss expectations. On the other hand, changes in the interpretation of signals reflect changes in how workers translate economic signals into job loss expectations. Both factors turn out to be important drivers of the observed decline in the propensity to hold job loss expectations in East Germany. In addition, we further scrutinize individual drivers of changes in job loss expectations, with expectations about changes in the firm's workforce proving most important.

1 There exists a large literature reporting mostly detrimental effects of job loss expectations on various outcomes. Dominitz/Manski (1997) find that job loss expectations vary with perceptions of crime risk or absence of health insurance. Aaronson (1998) and Campbell et al. (2007) find lower wage growth among males with higher job loss expectations. Benito (2006) finds negative effects on consumption and Lusardi (1998) and Carroll/Dynan/Krane (2003) document a positive association between job loss expectations and savings increases. Warr (1987), Wichert/Nolan/Burchell (2000) and Burchell/Ladipo/Wilkinson (2002) find increased job dissatisfaction among those who expect job loss. Expecting job loss is also found to negatively influence loyalty to the firm (Sverke/Goslinga (2003)), decrease motivation for respecting safety guidelines (Probst/Brubaker (2001)), increase the propensity of further training (Elman/O'Rand (2002)) and to affect fertility choices (Bernardi/Klärner/ Lippe (2008)). 
Our empirical analysis relies on subjective expectation elicited through a repeated survey. ${ }^{2}$ In contrast to many other studies, we can rely on a long-term panel data set (the German Socioeconomic Panel), in which job loss expectations were elicited repeatedly starting as early as 1990/91 in both East and West Germany. This allows us to merge job loss expectations with the actual job losses in the future, as well as to control in detail for changes in individual characteristics over time. ${ }^{3}$

German reunification induced a large negative employment shock in East Germany, and we document strong (over)pessimism regarding job security in the early 1990s. In 1991, nearly half of all East German workers expected to lose their job within the next two years (4 percent in West Germany at the same time). An actual job loss in the next two years was experienced by only 31 percent of these workers ( 7 percent in West Germany) implying that the share of East German workers expecting a job loss was much higher than the share of actual job losses and about 30 percent of East German workers in 1991 expected to lose their job in the next two years but did not do so. Until 1999, job loss expectations in East Germany converged to West German levels and remained stable thereafter. The remaining differences after 1999 can be explained by differences in actual job loss risk in East and West Germany. Job loss expectations in West Germany were quite stable and only a small share of workers expected a job loss. An analysis of the effect of a negative employment shock job loss expectations would be difficult in a setting like West Germany without substantial shocks to job loss risk. In contrast, East Germany offers a unique opportunity to study a substantial change in job loss expectations.

Our analysis focuses on explaining changes in the average propensity to hold job loss expectations over time based on cross-sectional regressions. Data limitations preclude analyzing individual level changes over time because job loss expectations are not elicited every year and only recorded for employed individuals. We first study the link between the strong changes in job loss expectations to changes in the economic signals perceived by workers. As one of the few contributions on this topic, Tortorice (2012) finds workers to be more pessimistic about the development of national unemployment at the end compared to the beginning of a recession, since they extrapolate too much from recent experiences into the future and thus do not take the stabilization of economic surroundings into account. Malmendier/ Nagel (2016) argue that this effect (extrapolation from recent experiences) is even stronger for younger individuals, since they have less past experience to draw upon. Such a pattern probably also applies to East Germans, since in the state-planned economy in the German

2 For job loss expectations, the analysis of subjective expectations elicited through surveys had been rare in the economic literature for many decades (Manski/Straub (2000)). However, starting with the pioneering work by Manski/Straub (2000)/Manski (2004) and others, empirical studies based on elicited expectations have increased, aided by an expansion of available data.

3 Kassenböhmer/Schatz (2017) use German data linking expectations of unemployed workers about reemployment probabilities with actual job finding to analyze the determinants of individuals correctly estimating job finding or under-/over-estimating their job finding probability, similar in spirit to our analysis of determinants of inaccurate expectations. Dickerson/Green (2012) analyze the same question in the GSOEP as we to and look at expectations and realizations of job loss, but they do not distinguish East and West Germany and they do not analyze changes over time. 
Democratic Republic (GDR), unemployment was largely absent and workers did not have to worry about job loss. Accordingly, individuals in East Germany turned overpessimistic initially after the negative employment shock caused by reunification, not foreseeing the subsequent stabilization in economic conditions, but then adapted their expectations once they received explicit signals of a stabilizing economic environment and learned more about the transmission of the shock. ${ }^{4}$

To explore the effects of changing economic signals, we focus on shifts in the value of different individual characteristics that should provide a good proxy for the economic situation of an individual worker. Our counterfactual analysis shows that if the interpretation of signals in East Germany had remained fixed at the level of 1991, shifts in the individual level control variables (endowments) alone would have induced a substantial decline in the prevalence of job loss expectations in East Germany, amounting to 50 - 60 percent of the actual decline between 1991 and 1999. This indicates that after an initial phase of uncertainty and inaccurate expectations, the stabilization of the East German economy contributed to the fall in the prevalence of (often incorrect) job loss expectations. However, the effect of changes in endowments depends strongly on the base year chosen for the values of the coefficients used for estimating the counterfactual, indicating that changes in the interpretation of economic signals play an important role for changes in job loss expectations. ${ }^{5}$

Workers may adapt the interpretation of economic signals by learning more about the signal's relevance for their individual job loss risk or about the information content of a signal change. The large reunification shock might have left workers unable to gauge correctly the relevance of labor market signals for their individual job loss risk initially, especially since after reunification most East Germans had to form job loss expectations for the first time. To study the extent of changes in interpretations, we compare the value of the coefficients of individual level determinants of job loss expectations over time, since they should offer a straightforward proxy for the average interpretation of market signals/the translation of market signals into job loss expectations. Furthermore, changing effects of different determinants on the likelihood of job loss should be informative about changes in the information content of specific signals. We demonstrate that changes in the interpretation of past and expected changes in the size of the worker's firm's workforce (as proxies for the firm's economic situation) show the largest changes in interpretation over time, meaning that workers change how they relate their assessment of the economic situation of their firm to their own job loss risk. In 1991, a pessimistic assessment of future employment changes in a worker's firm strongly increases job loss expectations and the effect is much larger than the increase in the actual job loss risk. The link to job loss expectations is much smaller in 1999. Thus, the subjective assessment of

4 Schmidt (1999) shows that expectation about aggregate unemployment move with the unemployment rate. Green/Felstead/Burchell (2000) find that changes in the unemployment rate affect perceived job security.

5 For a discussion of the formation of job loss expectations in East Germany right before and after reunification, see Lechner/Pfeiffer/Wagner (1994). Changes in the interpretation of signals are not studied extensively in the literature. Roth/Wohlfart (2020) or Armantier et al. (2016) provide causal evidence from experiments on how individuals update their expectations when new information become available, but do not investigate changes to the interpretation process. 
a worker's employer's economic situation emerges as the driving factor both for the changes in signals and for changes in interpretation.

As robustness checks, we distinguish different types of job loss and other subjective measures of the worker's economic situation apart from job loss expectations. Finally, we investigate the puzzle that East German workers who expect job loss, seem to be more accurate in their expectations than their West German counterparts in the early 1990s, which is surprising in light of overpessimism among East German employees. However, once differences in job loss risk are controlled for, West German workers who hold job loss expectations are more accurate in the early 1990s than East German workers. The accuracy of job loss expectations converges over time, and changes in the accuracy of job loss expectations are driven by changes in the interpretation of the firm's economic situation, in the composition of those expecting job loss in East Germany, and in the reasons for job loss.

The paper is structured as follows: Section 2 describes the setting of German reunification and Section 3 provides first information about the developments of job loss expectations and realizations in East and West Germany. Section 4 then analyzes the role of changes in signals and changes in the interpretation of signals to evaluate the observed dynamics and describe the convergence between East and West Germany. Section 5 discusses as robustness checks different reasons for job loss and different subjective assessments of a worker's economic situation other than job loss expectations. Section 6 analyzes the determinants of the seemingly higher accuracy of job loss expectations among those East German workers who expect job loss and compares it to findings for similar West German workers. Section 7 concludes.

\section{The Case of German Reunification}

Between the fall of the Berlin wall on the 9th November 1989 and the official reunification of the two parts of the country on the 3rd October the following year, steps for a swift political and economic union were implemented, including the harmonization of institutions, the introduction of the Western Deutschmark in East Germany, the start of the privatization of state owned East German enterprises and the expansion of the collective bargaining system to East Germany. Thus, market mechanisms were introduced into the East German economy, which stood in stark contrast to the command economy known from before. Individual workers could now make their labor market choices on their own and without inference by the state. However, this also meant that individuals suddenly faced the threat of unemployment, which had basically been absent in the GDR. Unemployment indeed increased sharply in the first years after reunification since many of the inefficient formally state owned companies were privatized, often reducing their workforce or being shut down altogether. 
The introduction of a market economy resulted in East German workers having to form expectations about their economic future, especially their risk of job loss in this changing economic environment. The developments in the labor market in East Germany in the years after reunification thus offer are a unique setting for analysing the development of job loss expectations of workers after a large negative shock to their economic surroundings. In contrast to many other settings, there exists a panel dataset, the German Socioeconomic Panel (GSOEP) which elicited expectations about job security and actual job loss from the East German workforce as early as 1990. Additionally, West Germany provides a well suited counterfactual for expectations in a settled market economy and also allows to account for shocks common to both parts of the country.

\section{Expectations in East and West Germany}

Job loss expectations of employed individuals in East and West Germany are directly elicited through the the question 'Do you expect to lose your job within the next two years'? The question was asked every year in East Germany from 1990 to 1994 and afterwards at least every second year. A complication is that even though the wording of the question remained the same over time, the scaling of the answers changed. From 1990 to 1998, individuals could choose among four ordinal responses, namely 'Surely not', 'Rather unlikely', 'Likely' and 'Surely'. In contrast, from 1999 onward, individuals were asked for their expected probability of job loss between 0 - 100 percent.

Since we analyze expectations over time starting as early in East Germany as possible, we need a unified indicator for job loss expectations. We choose a simple solution by creating a dummy variable for expected job loss, which is equal to 1 if the individual answered 'Likely' or 'Surely' on the ordinal scale or gave a probability of 60 - 100 percent on the cardinal scale and 0 if the individual answered 'Surely not' or 'Rather unlikely' or stated a job loss probability between 0 - 50 percent. ${ }^{6}$ To contrast this expectation indicator with what actually happened to workers, we also construct an indicator for future job loss realizations. This indicator is equal to 1 if individuals were unemployed at least one month in the 24 months following the interview. ${ }^{7}$ In addition, we restrict the sample to individuals who already entered the labor

6 Manski/Straub (2000) advocate the use of probabilistic answer scales for eliciting expectations, since they are less ambiguous and thus less prone to heterogeneity in individual interpretations of the answers compared to ordinal response scales. According to Dickerson/Green (2012) answers in the GSOEP based on the probabilistic scale are better at predicting subsequent job loss. However, the probabilistic answers are not available in the early 1990s, the time of the largest changes in job loss expectations in East Germany.

7 This might overestimate actual realizations since a month in unemployment can also constitute a voluntary break between two jobs. It could also underestimate realizations if individuals change employers to pre-empt a lay off in the future or change into unregistered unemployment. However, since voluntary and involuntary unemployment are difficult to distinguish for a substantial part of the sample, we use the broader definition. 
market during GDR times. ${ }^{8}$ Also note that, since individuals are asked if they expect to lose their current job, the displayed results are based on individuals who are employed at the time of the survey.

Figure 1: Shares of Job Loss Expectations and Realized Unemployment

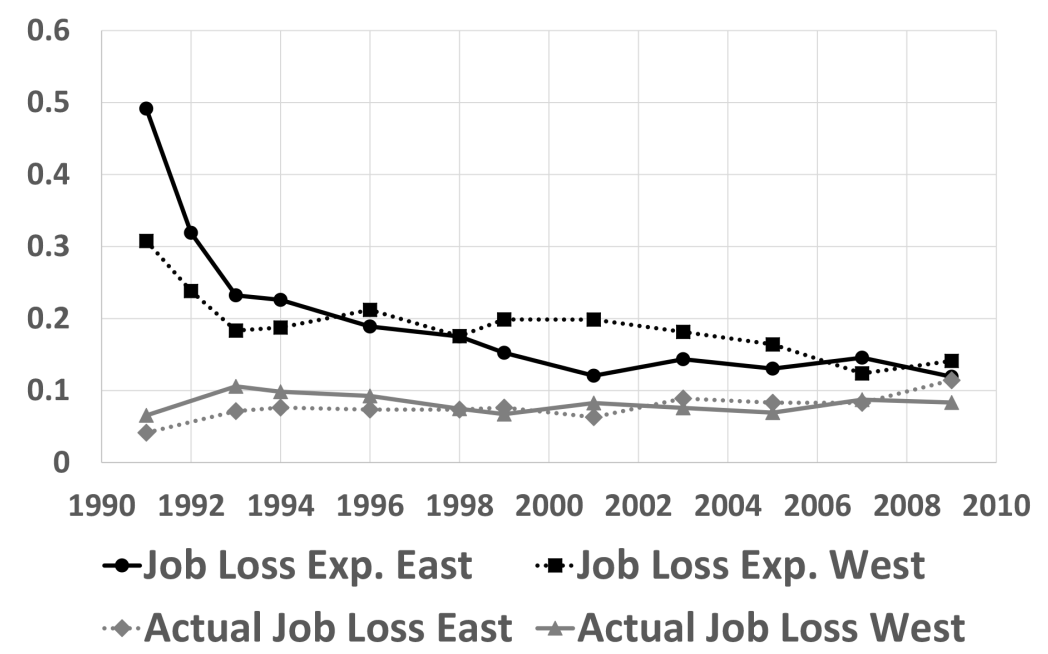

Note: The share of job loss expectations is based on the year of the interview, whereas the share of actual unemployment is based on job loss in the 24 months after the interview in a given year.

Source: Own calculations based on the GSOEP.

Figure 1 displays the shares of job loss expectations and actual job loss (within the next two years) based on the two indicators for East and West Germany. Our expectation indicator seems to make the expectation data based on different answer scales comparable because there is no apparent break in any series in 1999. For West Germany, the shares of job loss expectations and actual job loss are quite stable over time and both shares are quite low, lying always between 5 - 10 percent. This seems to be a common finding in times of economic stability, see Schmidt (1999) for the US, Lübke/Erlinghagen (2014) for most European countries, and Dickerson/Green (2012) for Australia and Germany. In East Germany from 1996 onward, 10 - 15 percent of all worker expect a job loss and the job loss rate is of similar magnitude except for being a bit larger in the late 1990s and early 2000s. By the late 2000s, the rates in East Germany have converged to West German levels. In contrast, there are remarkable differences in the early 1990s. In 1990 and 1991, almost 50 percent of workers in East Germany expected to lose their job, whereas the job loss risk was at about 30 percent, only 10

Additionally, job changes without any period of unemployment in-between jobs are also not counted as job loss. Note as well that early retirement is counted as job loss, since this was a common option among East German workers to avoid becoming unemployed in the early 1990s in East Germany. Early retirees are defined as workers between 40 and 59 years of age who go into retirement and never work again after the onset of retirement. The vast majority of these early retirements in our sample happened in 1990 and 1991 in East Germany.

8 To increase comparability, we only include individuals who already worked before 1990 in West Germany in the West German sample. We also only consider observations of workers who are younger than 60 years at the time job loss expectations are elicited, to avoid issues with retirement. Due to its special status as a divided city, workers living in Berlin are excluded from the analysis. 
percentage points ( $\mathrm{pp}$ ) higher than in the late 1990s. This alone is remarkable, but even more interesting is the subsequent decline in job loss expectations until 1996, job loss expectations and the share of expected job loss had aligned and continued to converge to West German levels.

Even though the shares of expected job loss and actual job loss are very similar both in East Germany after 1996 (except 2001) and in West Germany during the entire time period, those who expect job loss are not necessarily the ones losing their job. In order to assess the accuracy of expectations, we calculate the 'confusion matrix' (displayed in Table 5 in the Appendix). The matrix displays the frequencies of job loss expectation and actual job loss with correct predictions on the diagonal and false predictions in the off-diagonal elements. Correct predictions are denoted by 'Correct Work (CWo)' [ $\equiv$ 'True Negative'] and 'Correct UE (CUe)' [三 'True Positive'], where Wo and Ue represent the predictions. The incorrect predictions are denoted by 'False Work (FWo)' [E 'False Negative'] and 'False Unemployed (FUe)'[ Positive']. In the following, we also refer to FWo as 'Optimistic' and FUe as 'Pessimistic'. The accuracy of the predictions is defined as the share of all correct predictions among all predictions:

Accuracy $=\frac{N(C W o)+N(C U e)}{N(C W o)+N(F W o)+N(C U e)+N(F U e)}$

where $N(j)$ denotes the number of observations for the expectation-realization case $j \in$ $\{C W o, F W o, C U e, F U e\}$. Figure 2 displays the time trend in the accuracy of predictions in East and West Germany. The accuracy rate for West Germany amounts to about 90 percent, which is a typical level for an established market economy, and changes little over time. In contrast, the accuracy rate in East Germany in the early 1990s is much lower (63 percent in 1991), which results from the high rate of workers falsely expecting job loss. Over time, the accuracy of job loss expectations in East Germany increases to 83 percent in 1998/99, but a level difference of 5 - 10 pp to West Germany remains. 
Figure 2: Accuracy of Job Loss Expectations

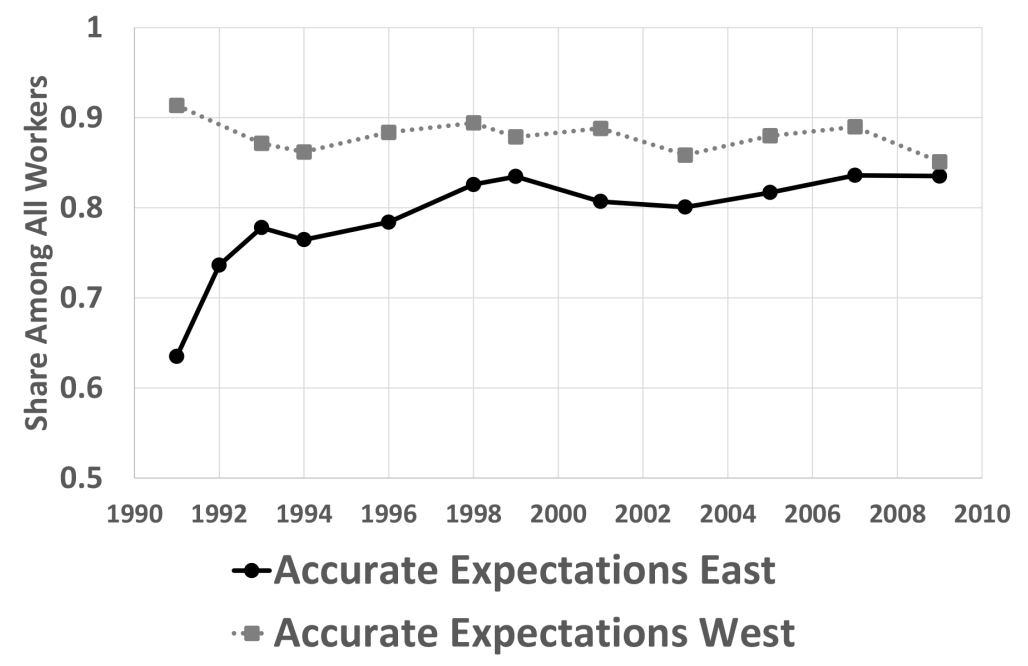

Note: Accurate Expectations are not expecting job loss and not losing one's job and expecting job loss and actually losing one's job. The share of job loss expectations is based on the year of the interview, whereas the share of actual unemployment is based on job loss in the 24 months after the interview in a given year.

Source: Own calculations based on the GSOEP.

Decomposing the accuracy rate, Figure 3 displays the shares of the four different combinations of the expectation and the realization indicator $N(j) /[N(C W o)+N(F W o)+N(C U e)+$ $N(F U e)]$. Workers who do not hold job loss expectations and who do not experience job loss (80-90 percent of workers in West Germany and 74-80 percent in East Germany after 1998) contribute most to the accuracy of job loss expectations. In contrast, correct predictions of unemployment are held by only a small and falling fraction of workers, except for East Germany in the early 1990s. Inaccurate expectations (optimism and pessimism) are low in West Germany in all years, whereas the low level of accuracy in East Germany in the early 1990s is driven by a high degree of pessimistic expectations (around 27 percent of all workers in 1990/91 in East Germany). The increase in accuracy in East Germany during the 1990s is thus driven by a decline in pessimism, with the level of pessimism being very similar to West Germany from the end of the 1990 s onwards. ${ }^{9}$

9 Figure 17 in the Appendix displays the more disaggregated indicator for job loss for the years 1991, 1993, 1996, and 1998. In 1991, 13 percent of East German workers expect to surely lose their job whereas 36 percent of workers deem job loss likely. Our aggregated indicator classifies workers in these two groups who do not lose their job during the next two years as pessimistic, which might overstate the level of pessimism for those who deem job loss as 'likely'. For simplification, our analysis focuses on the aggregate indicator. This is justified because our main empirical analysis of the drivers of the decline in job loss expectations in East Germany yields very similar results for the aggregate indicator and a more disaggregate indicator. 
Figure 3: Shares of Expectation-Realization Pairs

Correct Work and Pessimistic

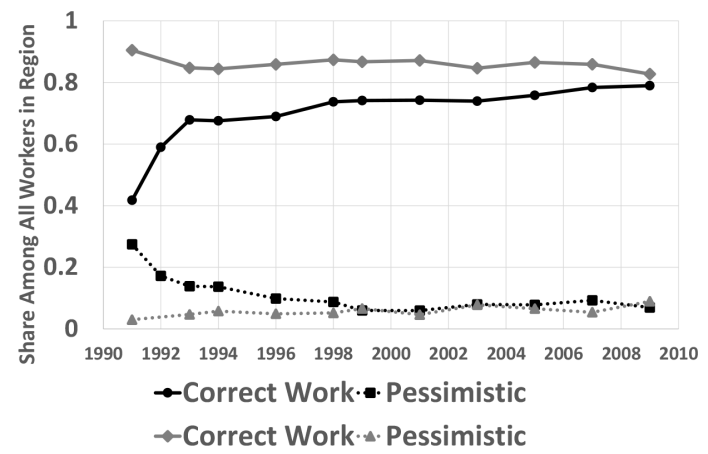

Optimistic and Correct UE

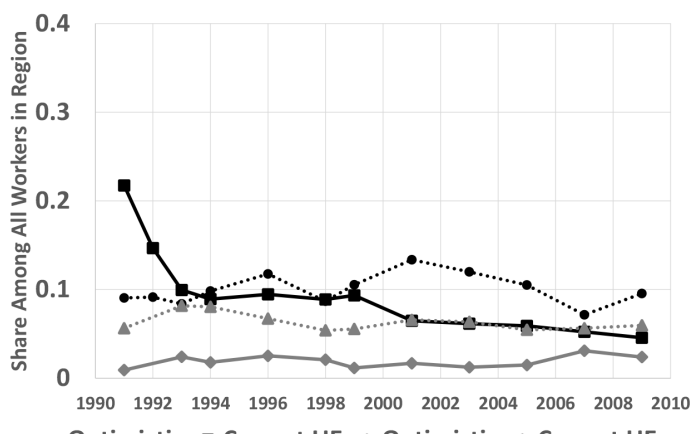

Note: Correct Work refers to workers who are not expecting job loss and not losing their job. Pessimistic workers are those workers who expect job loss but don't lose their job. Optimistic workers are workers who do not expect job loss but actually lose their job. Correct Unemployment refers to workers who expect to lose their job and actually lose their job. Expectation-Realization pairs are based on job loss expectations in a given year and job loss within the subsequent 24 months (after the interview).

Source: Own calculations based on the GSOEP.

The high accuracy level may suggest that West German workers are very good in assessing their employment prospects. However, the prediction problem is rather imbalanced, with actual job loss being a much rarer event than staying employed. Thus, even if every worker did not expect a job loss, the accuracy would still be high, especially in West Germany with its low job loss rate. Two measures that do not suffer from this imbalance are the shares of actual job loss conditional upon predicting or not predicting a job loss (as discussed for example in more general terms in Chawla et al. (2002)). Formally, these are given by $N(C U e) /[N(C U e)+N(F U e)]$, the share of correct prediction conditional upon predicting a job loss and $N(F W o) /[N(C W o)+N(F W o)]$, the share of incorrect predictions conditional upon not predicting a job loss. 
Figure 4: Realized Unemployment Conditional on Job Loss Expectations

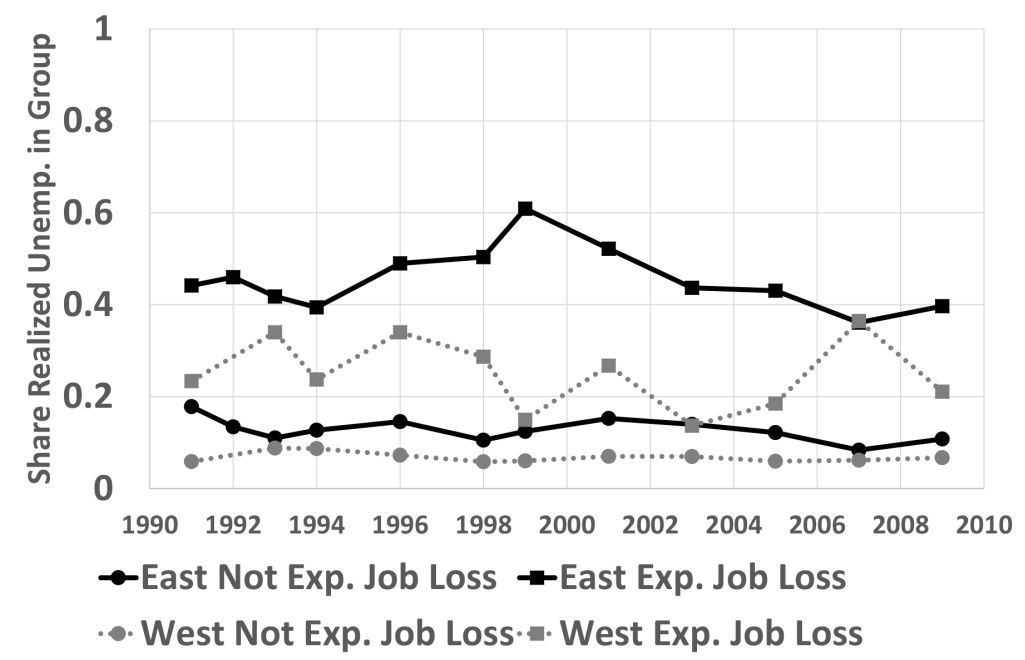

Note: The share of job loss expectations is based on the year of the interview, whereas the share of actual unemployment is based on job loss in the 24 months after the interview in a given year.

Source: Own calculations based on the GSOEP.

Figure 4 shows how these shares evolve over time. Workers not expecting a job loss have a low job loss risk in both East and West Germany. Those who do expect a job loss show a considerably larger actual job loss risk, being much larger in East Germany than in West Germany. Still, even for workers expecting job loss, actual job loss is not a very likely event. In West Germany, it never exceeds 40 percent and it only exceeds 50 percent in East Germany during the late 1990s (see also Stephens (2004) and Dickerson/Green (2012)). Thus, workers in both parts of the country are overpessimistic on average. At the same time, East Germans are much more likely to correctly predict job loss than West Germans, with a rising gap 1994 and 1999 and a slow decline afterwards (except for a spike in 2007). The findings for East Germany are somewhat surprising in light of the large overpessimism in the early 1990s, when between 50 percent and 60 percent of those expecting a job loss actually keep their job. The latter share is even larger in West Germany, but since only a small share of workers expects a job loss in West Germany, the overall share of pessimists among all West German workers is low. In light of the high share of pessimists in East Germany and the growing overall prediction accuracy in the 1990s (recall that the risk of unemployment declines over time), we conclude that some East German workers were good at predicting job loss, but a large share of workers was bad at predicting job stability. This issue is investigated further as part of the following decomposition analysis where we hold actual job loss risk constant. 


\section{Explanations}

Two factors stand out as possible drivers of the high prevalence of job loss expectations in East Germany in the early 1990s: The high job loss risk immediately after German reunification and a possible misinterpretation of economic signals due to the transformation shock. Job loss in East Germany may simply have been difficult to predict in the early 1990s, thus rendering the high level of job loss expectations not so surprising. It is likely that the economic stabilization in the aftermath of the initial shock or a changing assessment of economic signals by workers are the main drivers behind the observed convergence of the share and accuracy of job loss predictions towards West German levels.

To investigate this in greater detail, our main analysis involves logit regressions for the outcome variables job loss expectation, actual job loss, and accurate job loss expectation. In addition regressions with the four expectation-realization pairs as outcomes are estimated. We use data for the years 1991, 1992, 1994, 1996, and 1999, which is the time period covering most of the convergence in job loss expectations between East and West Germany. Our rich set of control variables includes gender, education, state of residence, occupation, industry, indicators for the unemployment history, residence in urban versus rural area, firm size, firm-level actual employment change during the last 12 months and expectations about the firm-level employment change during the next 12 months. And, in addition, age, age ${ }^{2}$, wages, industry tenure, and firm tenure, standardized (by year). We focus on 1991 and 1999 as the start and end point of the strong convergence pattern.

Our sample is restricted to workers who were in the labor market in 1990. For 1991 (1999), this includes 1871 (945) workers in East Germany and 3503 (2192) workers in West Germany. To assess the effect of panel attrition, we also analyze the subsamples of workers still in the sample in 1999, excluding migrants or requiring workers to be employed both in 1991 and 1999. The shares and dynamics of job loss expectations, actual job losses, and accurate expectations change little under different sample restrictions, details are available upon request.

In a first step, we show that there was substantial variation in predicted job loss expectations in East Germany in 1991, indicating that signals in the early 1990s were informative about actual job loss risk, and discuss job loss expectations for workers with different predicted job loss risk. In the next step, we undertake a non-linear Blinder-Oaxaca decomposition (Fairlie, 1999) between the years 1991 and 1999 - using the Stata code of Sinning/Hahn/Bauer (2008) to distinguish changes in the economic signals received by workers (the 'endowment effect') from changes in the interpretation of signals (the 'coefficients effects') and, regarding the latter effect, discuss changes of the effects of individual signals. 


\subsection{Job Loss Risk and Expectations}

To investigate job loss expectations for workers with different job loss risk, Figure 5 shows the distribution of job loss risk in different years in East Germany and displays the share of the four expectation-realization pairs for different groups of workers based on their predicted job loss risk based on the logit regressions described above. There is substantial variation in predicted job loss risk in 1991. About 27 percent of workers show a high predicted job loss risk ( $>40$ percent) and 16 percent/ 25 percent, respectively, show a low predicted job loss risk ( $\leq 10$ percent/between 10 percent and 20 percent). These figures drop quickly over time with 12 percent of workers having a high predicted job loss risk and 60 percent/19 percent of workers, respectively, with a low predicted job loss risk in 1999.

Figure 5: Job Loss Risk and Expectation-Realization Pairs East Germany

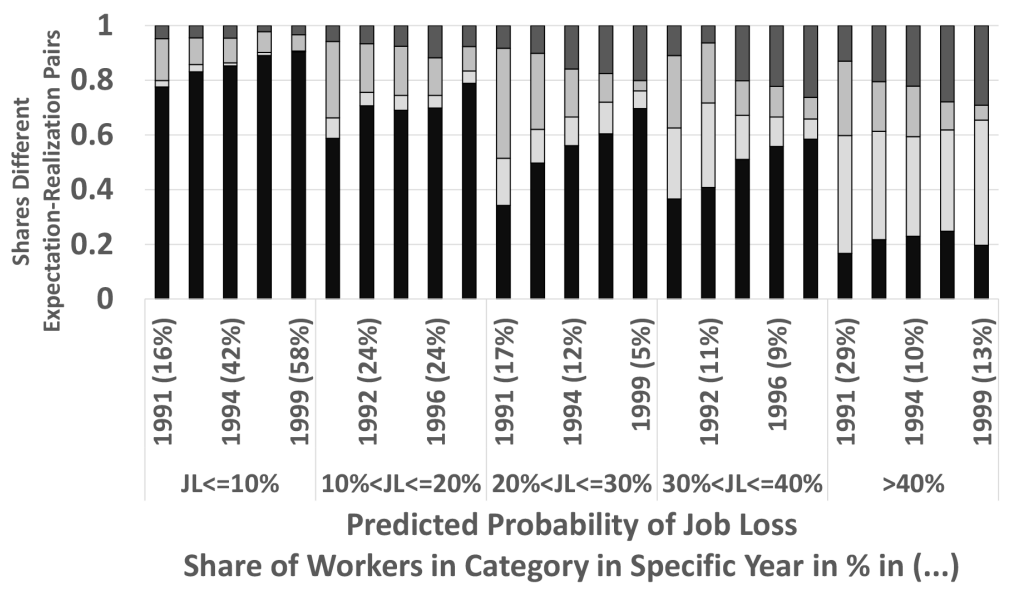

n Correct Work $\square$ Correct UE $\square$ Pessimistic $\square$ Optimistic

Note: Predicted job loss risk is based on separate logit regressions for every year using the control variables described in the text. Source: Own calculations based on the GSOEP.

Turning to the shares of the different expectation-realization pairs, workers with very low predicted job loss risk ( $\leq 10$ percent) were actually very accurate in their expectations already in 1991. In contrast, workers with an slightly higher predicted job loss risk show a substantial degree of pessimism in 1991. The share of pessimists declines in all groups over time, while the share of optimists increases for those with a high predicted job loss risk. Since the latter group shrinks strongly over time, this effect only concerns a small share of workers. Altogether, these findings reveal a substantial explanatory power of individual signals for job loss risk already in the early 1990s, with declining pessimism for all levels of job loss risk and a shift towards lower predicted job loss risk over time driving increasing expectation accuracy in East Germany. 
Figure 6: Job Loss Risk and Expectation-Realization Pairs West Germany

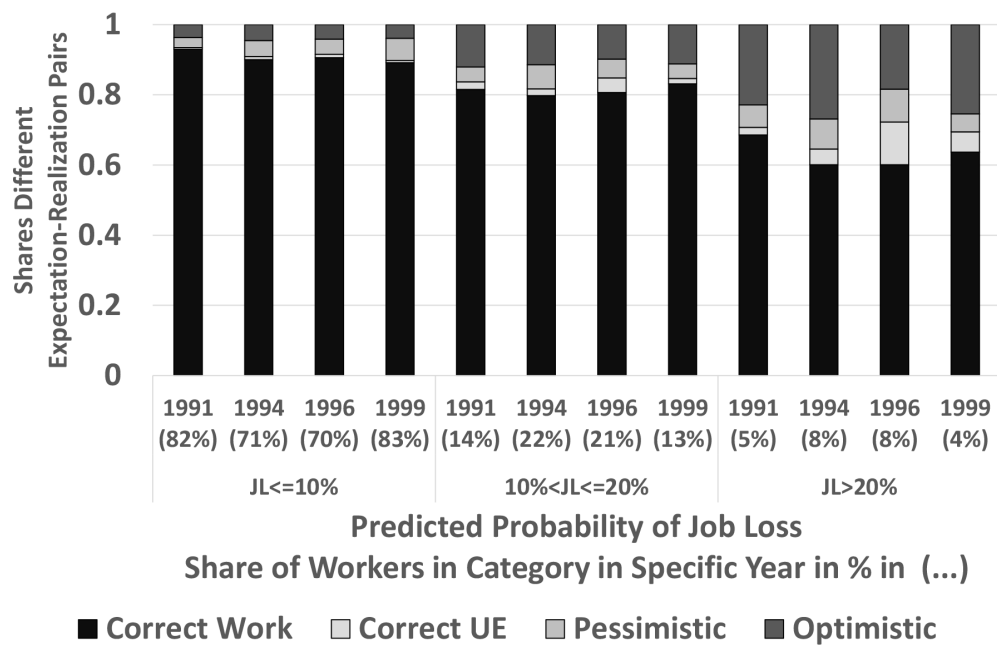

Note: Predicted job loss risk is based on separate logit regressions for every year using the control variables described in the text. Source: Own calculations based on the GSOEP.

Figure 6 shows that the distribution of expectation-realization pairs for East and West Germany converged strongly over time given the predicted job loss risk, with the distribution in West Germany remaining almost constant over time. However, a comparison of the two figures reveals that predicted job loss risk in East Germany in 1999 is still much higher than in West Germany. ${ }^{10}$

\subsection{Effects of Stabilizing Economic Conditions}

To assess the impact of stabilizing economic conditions, we estimate a counterfactual scenario for the evolution of job loss expectations based on the changes in endowments in a non-linear Blinder-Oaxaca decomposition. This counterfactual describes the development of job loss expectations, if the interpretation of signals had remained as it was in 1991, but the individual level signals changed as they actually did. ${ }^{11}$ This involves first estimating a logit regression in 1991 with job loss expectations as dependent variable and then using the coefficients from this regression to predict the values of the job loss indicator for each individual up to 1999. Since the coefficients for predictions are the same for all years, the changes

10 Note that due to the very low number of West German workers with job loss risk $>30$ percent, workers with job loss risk of $>20$ percent have been aggregated in one category.

11 Formally, we estimate for each year $t=92,94,96,99$ (dropping the first two digits of the years), $E_{X_{i, t}}\left[P\left(y_{i, t}=1 \mid X_{i, t}, \beta_{91}\right)\right]-E_{X_{i, t}}\left[P\left(y_{i, 91}=1 \mid X_{i, 91}, \beta_{91}\right)\right]$, which is the difference between the average counterfactual probability for the signals in year $t$ /coefficients in year 91 and the average actual probability for the signals in year 91 /coefficients in year 91 . Here, $i=1, \ldots, N_{t}$ denotes the individuals in the sample for year $t, \beta_{91}$ the logit regression coefficients the year 91 , and $E_{X_{i, t}}$ the unconditional expected values integrating out the distribution of $X_{i, t}$ based on the law of iterated expectations. For year $t$, the counterfactual $E_{X_{i, t}}\left[P\left(y_{i, t}=1 \mid X_{i, t}, \beta_{91}\right)\right]$ can be estimated by the sample average $\frac{1}{N_{t}} \sum_{i=1}^{N_{t}} \Omega\left(\hat{\beta}_{91} X_{i, t}\right)$ where $\Omega($.$) is the$ link function for the logit regression. For $t=91$, this is an estimate of the expectation for the actual sample. 
in the counterfactual outcome over time reflect the changes in individual level determinants. Finally, we also conduct the same counterfactual analysis using the 1999 coefficients for predicting job loss expectations in previous years. This alternative approach shows how changing signals would have affected job loss expectations if workers would have interpreted signals in 1991 (and subsequent years) as they did in 1999.

Figure 7: Predictive Power of Changes in Signals for the Share of Job Loss Expectations with Coefficients from 1991

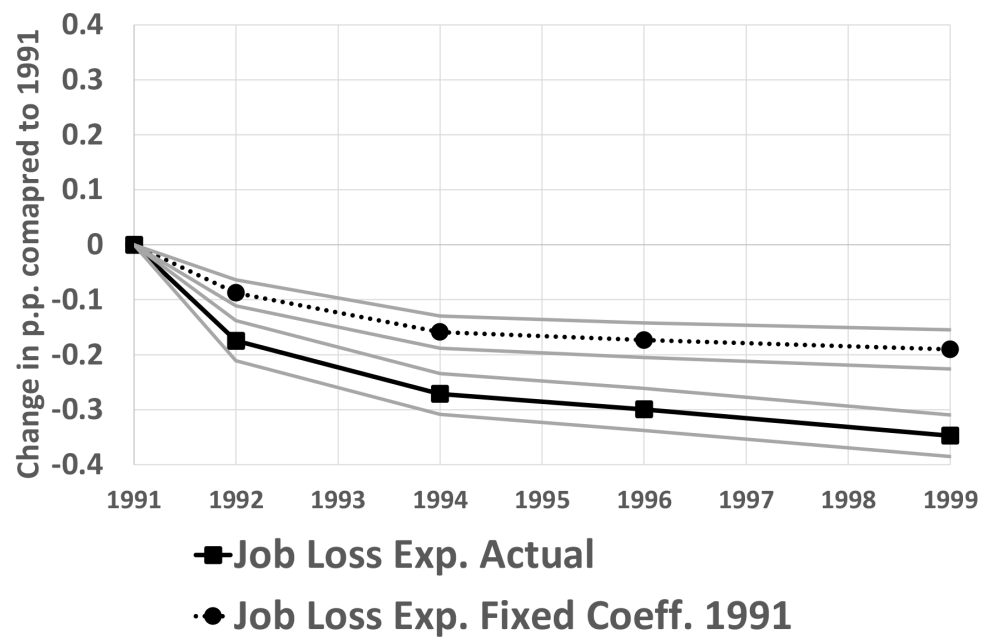

Note: The graphs are obtained by first predicting the value of the job loss expectation dummy for each worker and in each year, based on coefficients from a logistic regression using data from 1991 only. Shares are the averages of these predicted values across all workers. This is contrasted with the actual changes in the share of job loss expectations. The displayed shares are the differences in percentage points (pp) compared to the shares in 1991. The grey lines denote 95 percent confidence intervals. Confidence intervals are obtained by bootstrapped standard errors clustered by individual, using 500 repetitions.

Source: Own calculations based on the GSOEP.

Figure 7 shows the pp changes compared to 1991 in the share of job loss expectations as well as in the predicted shares based on changes in endowments using coefficients from 1991 for prediction. The development of the actual shares in the two graphs reflect the decline in job loss expectations visible in Figure 1.12 Based on predictions using 1991 coefficients, changes in signals would have induced a decline in job loss expectations between 1991 and 1999 of 55 percent of the actual decline, assuming workers would have adapted their expectations in accordance to the new signals. Thus, stabilizing economic conditions alone would have led to a decline in job loss expectations of more than half of the actual decline. These findings are unchanged when using different samples (compare Figure 18 in the Appendix). ${ }^{13}$

\footnotetext{
12 The grey lines outline 95 percent confidence intervals. Confidence intervals are obtained by bootstrapped standard errors clustered by individual, using 1000 repetitions, where in each repetitions, the prediction process is run anew.

13 Note, that the job loss expectations for Sample 1 (the 'overall" sample) differ slightly from those in the text. Having a university degree or answering 'Don't Know' to the question about expected changes in firm employment are perfect predictors for job loss expectations in some years in some samples, so dummies for the two categories have been taken out as control variables to ensure comparability across different samples and years. The differences in predicted changes in the overall sample are very small when comparing the results with and without these control variables.
} 
Next, we focus on the main drivers behind the changes in economic signals. While most individual level determinants show little change over time, two factors stand out as changing considerably between 1991 and 1999, namely industry affiliation and changes in firm employment (past and expected).

Liepmann (2018) documents substantial changes in the employment shares of different industries in East Germany. In particular, employment in manufacturing/agriculture fell strongly, whereas services and construction expanded. ${ }^{14}$ Figure 8 shows the development of the employment shares of several industries in East Germany over time. Our data mirrors the findings in Liepmann (2018). The employment share in services increased from 27 percent in 1991 to 42 percent in 1999 whereas it decreased for manufacturing, agriculture, energy and mining from 38 percent to 24 percent ( 21 percent in 1996). Since job loss expectations differ across industries, this shift in the industry composition could have influenced the development of job loss expectations in East Germany.

Figure 8: Industry Employment Shares in East Germany

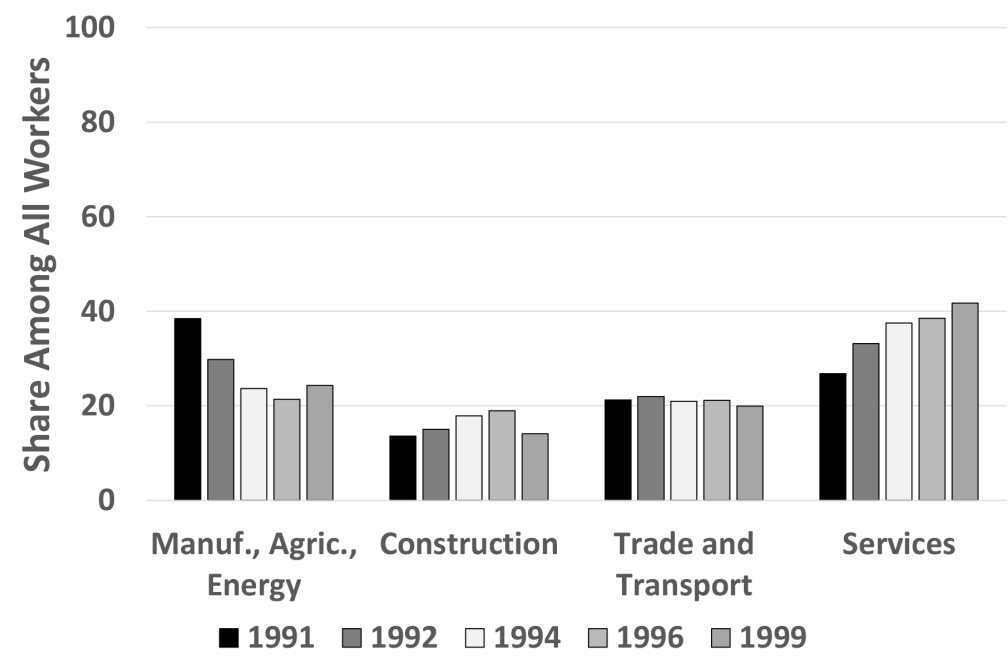

Source: Own calculations based on the GSOEP.

The other factor displaying substantial change over time is the economic situation of a worker's firm as measured by the reported change in employment of a worker's firm in the last 12 months and by the expected changes in employment in the next 12 months. Figure 9 shows a strong improvement in both measures over time, note in particular the decline in the category 'decrease'. In 1991, about 68 percent of workers report that the workforce of their firm declined in the past 12 months and 64 percent expect a decline in the next 12 months. Only about 29 percent report that the workforce has been unchanged or has increased in the last year and the same share expects it to do so. However, the share of workers expecting or re-

14 Liepmann (2018) shows that industry affiliation and consequently employment expectation had an impact on the fertility of East German women. 
porting a decrease in the workforce falls to 28 percent for past changes in 1999 and to 23 percent for expected changes, whereas the share of workers who report a constant or increased workforce rises to 65 percent (61 percent for expectations). The strong decline in reported and expected employment reductions shows a stabilization of the employment situation in many firms over time (however at a lower level than before).

Figure 9: Expected and Past Changes in Firm Employment

Expected Change in Firm Employment

100

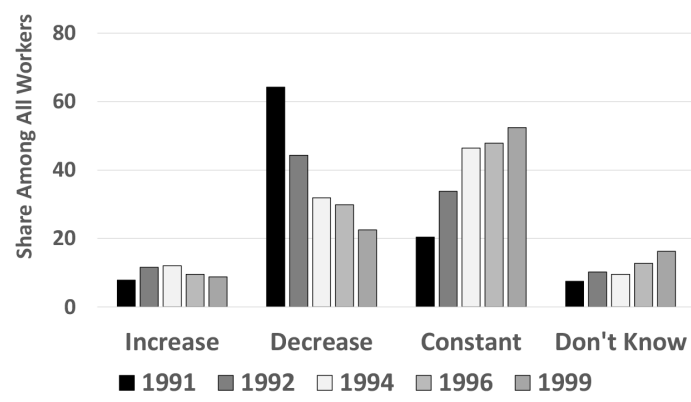

Past Change in Firm Employment

100

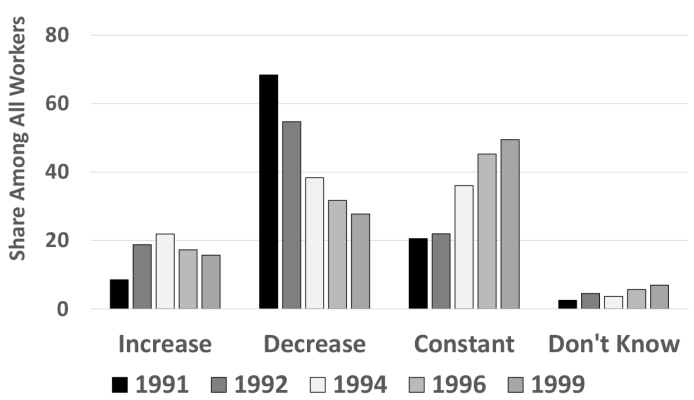

Note: Each bar within each expected/past change in firm employment category represents the share of workers who expect/report the specific change in firm employment in a given year.

Source: Own calculations based on the GSOEP.

To assess the explanatory power of shifts in the industry composition and past or expected changes in firm employment, we undertake a counterfactual analysis similar to the one above, now holding fixed both the 1991 coefficients and the industry affiliation or the past/expected changes in firm employment, respectively. ${ }^{15}$ The predicted values thus only pick up the influence of the changes in those covariates not held fixed. Figure 10 shows that fixing the industry structure does not strongly affect predictions. In contrast, fixing the distribution of past changes in firm employment leads to a lower predicted decline in job loss expectations, and fixing expected changes in firm employment strongly decreases the explanatory power of changes in signals. This means that job loss expectations were strongly influenced by the

15 Let $X_{i, t}^{I_{j}}$ be a dummy for belonging to industry $\mathrm{j}$ (with $\mathrm{j}=1,2,3,4$ ) and $X_{i, t}^{-I}$ collecting the values of all other covariates expect industry affiliation for individual $i$ in period t. To obtain the counterfactual development of job loss expectations, we first use a multinominal logit model with industry affiliation as dependent variable in 1991 to predict the probability to belong to each of the four industries as a function of $X_{i, 91}^{-I}$ (using coefficients $\gamma_{91_{j}}$ for industry $j$ - the vector of coefficients is summarized by $\left.\gamma_{91}\right)$. Then, using the same method as above, we predict job loss expectations in years 1991, 1992, 1994, 1996, and 1999 using coefficients $\left(\hat{\beta}_{91}\right)$ from a logit regression with job loss expectations as dependent variable. Then we predict job loss expectations for each individual in every year separately for the four different possible industry affiliations and then compute an individual weighted average across these four predicted probabilities of job loss expectations using the predicted industry affiliations from 1991 as weights. Average counterfactual job loss expectations in a given year are then the sample average of these individual weighted averages. Thus, formally we compute $E_{X_{i, t}, X_{i, 91}^{I}}\left[P\left(y_{i, t}=\right.\right.$ $\left.\left.1 \mid X_{i, t}, X_{i, 91}^{I}, \beta_{91}, \gamma_{91}\right)\right]=\frac{1}{N_{t}} \sum_{i=1}^{N_{t}} \sum_{j=1}^{4}\left[\operatorname{Pr}\left(X_{i, 91}^{I_{j}}=1 \mid \hat{\gamma}_{91}, X_{i, 91}^{-I}\right) \cdot \Omega\left(\hat{\beta}_{91, j} X_{i, t} \mid X_{i, t}^{I_{j}}=1, X_{i, t}^{I_{-j}}=0\right)\right]$. The same method is also applied for fixing the values of past or expected changes in firm employment. 
economic situation of the employer (rather than the general industry affiliation) and that the stabilization of the economic environment over time can explain part of the decrease in job loss expectations (and pessimism) among East German workers in the mid and late 1990s.

Figure 10: Predictive Power for the Share of Job Loss Expectations fixing Industry Affiliation or Past or Expected Changes in Firm Employment

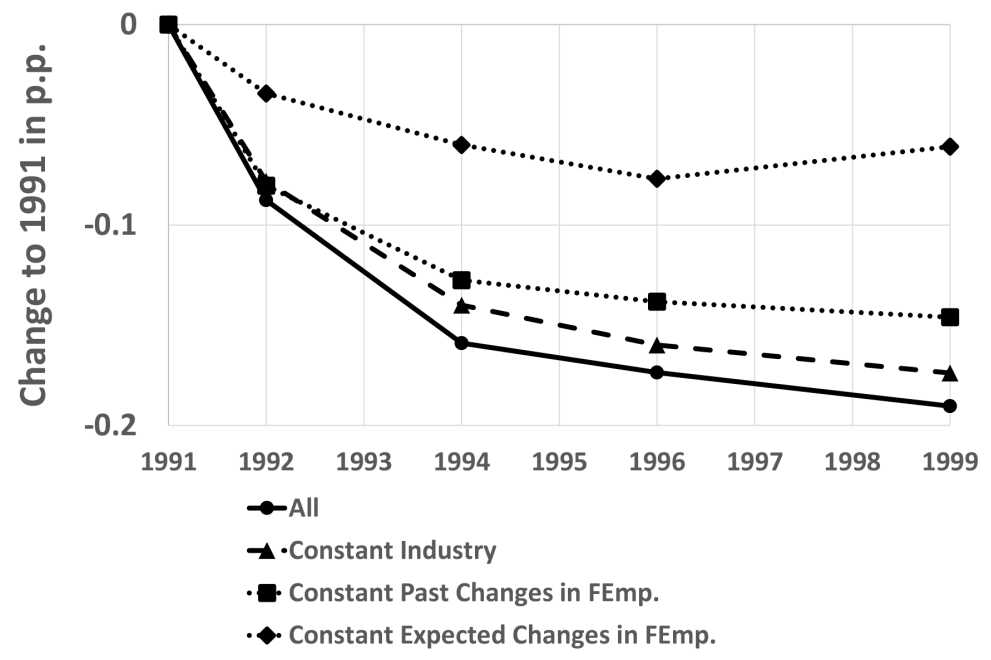

Note: The graph shows counterfactual (predicted) job loss expectations based on coefficients of a logistic regression in 1991 with job loss expectations as dependent variable ('All'). Additional counterfactuals are shown in which all control variables are allowed to change over time, but the industry affiliation, past changes in firm employment or expected changes in firm employment are fixed at 1991 levels. For the exact method, see the text.

Source: Own calculations based on the GSOEP.

While most covariates are straightforward to interpret, the changes in firm employment involve some ambiguity. First, expectations about the future firm employment are themselves the result of an expectation formation process, and as such they might not represent 'external' economic signals. Also, issues of reverse causality might arise, if individuals who do not expect to be laid off also do not expect lay-offs in their firms, instead of the other way around. However, after excluding expected workforce changes as a predictor from the analysis while keeping past changes in firm employment, which should be less prone to reverse causality or influence by an unobserved factor not actually impacting a firm's health, changes in economic signals still yield substantial explanatory power for the decline in job loss expectations (the predicted decline is about 30 percent smaller than before as displayed in Figure 20 in the Appendix). Past changes in firm employment thus seem to exert a substantial influence on the worker's expectation of firm employment in the future, which thus to a large extent reflect external economic developments. This suggests that reverse causality is not the driving force for the above results.

The second source of ambiguity arises from the fact that the magnitude of the past/expected changes might differ, since the question only concerns the direction of change. Since the effects of reunification shock were much stronger in 1991 than in 1999, past and expected 
changes in firm employment were presumably larger in magnitude in 1991 than in 1999, with stronger effects on job loss expectations. Thus, the estimated impact of changes in signals might even somewhat underestimate the impact of changing economic conditions.

The findings so far point to a strong role of changes in the economic environment for changes in the prevalence of job loss expectations. However, the magnitude of the estimated effect of changes in signals strongly depends on the base year used for prediction and is much lower when using 1999 coefficients, amounting to at most 26 percent of actual changes as shown in Figure 11 compared to more than 50 percent in each year when coefficients from 1991 are used. Some of the variables with the largest changes over time show the largest changes in coefficients, thus indicating a reduction in their relevance for job loss expectations. Correspondingly, the explanatory power of changes in covariates falls over time (Figure 19 in the Appendix). This shows that the interpretation of economic signals changes over time. The results using coefficients from 1999, which are quite close to West German coefficients, also suggest that a large negative shock to job loss risk would not lead to a large reaction in job loss expectations in West Germany (or in later years in East Germany) if the interpretation of economic signals remains unchanged. For an overly large increase in job loss expectations as visible in the early 1990s in East Germany, it needs both, a large negative shock and a misinterpretation of economic signals.

Figure 11: Predictive Power of Changes in Signals for the Share of Job Loss Expectations with Coefficients from 1991 or 1999

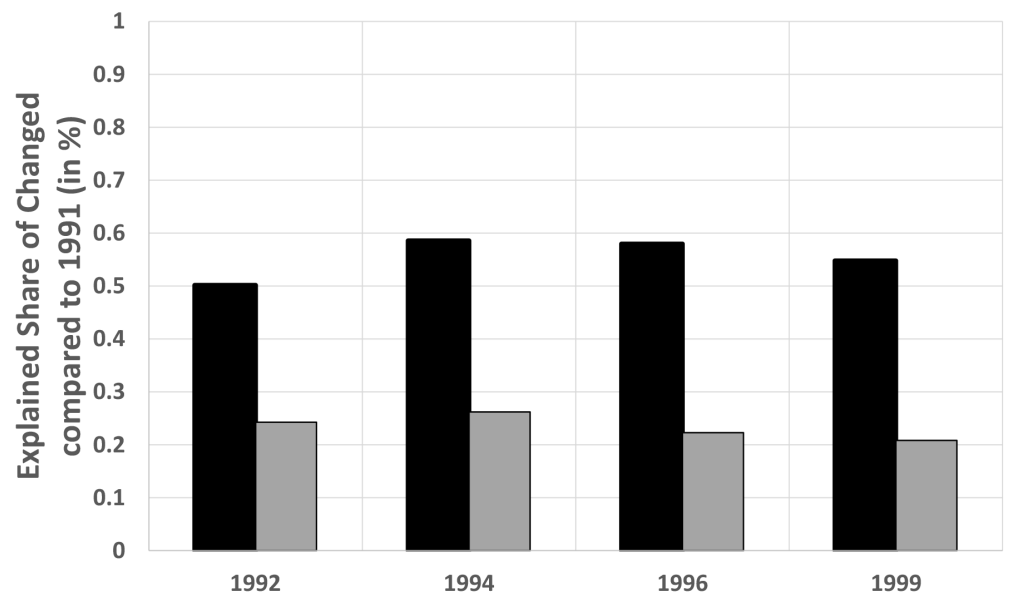

- Coefficients from $1991 \square$ Coefficients from 1999

Note: The graphs are obtained by first predicting the value of the job loss expectation dummy for each worker and in each year, based on coefficients from a logistic regression using data from 1991 or 1999 separately. The explained shares is then the difference in the average predicted share in a given year and the predicted value in 1991 divided by the actual difference between the share of job loss expectations in a given year and 1991. Formally this means ExpShare $t_{t}=\frac{\frac{1}{N_{t}} \sum_{i}^{N_{t}} \hat{\operatorname{Pr}} r\left(y_{i, t}=1 \mid X_{i, t}, \beta_{k}\right)-\frac{1}{N_{9} 1} \sum_{i}^{N_{9} 1} \hat{\operatorname{Pr}} r\left(y_{i, 91}=1 \mid X_{i, 91}, \beta_{9} 1\right)}{\frac{1}{N_{t}} \sum_{i}^{N_{t}} \operatorname{Exp}_{i, t}-\frac{1}{N_{9} 1} \sum_{i}^{N_{9} 1} \operatorname{Exp}_{i, 91}}$ where $\operatorname{Exp}_{i, t}$ is a dummy for expecting job loss in year $t$.

Source: Own calculations based on the GSOEP. 


\subsection{Effects of Changing Interpretations}

Recall that changes in signals alone explain at most 55 percent of the overall decrease in job loss expectations between 1991 and 1999 and the share varies with the chosen base year for the counterfactual prediction. These findings suggest an important role for changes in the interpretation of signals as represented by changes in coefficients. We now scrutinize the changes in the coefficients of the determinants of job loss expectations, actual job loss, and accurate expectations in 1991 and 1999.

Table 1: Determinants of Expectation, Unemployment and Accurate Expectations in East Germany in 1991 and 1999

\begin{tabular}{|c|c|c|c|c|c|c|}
\hline \multirow[t]{2}{*}{ Dependent Variable } & \multicolumn{2}{|c|}{ Job Loss Expectations } & \multicolumn{2}{|c|}{ Actual Job Loss } & \multicolumn{2}{|c|}{ Accurate Expectations } \\
\hline & 1991 & 1999 & 1991 & 1999 & 1991 & 1999 \\
\hline \multicolumn{7}{|l|}{ Change Firm Emp. } \\
\hline \multicolumn{7}{|l|}{ Previous Year } \\
\hline Increased (Reference) & - & - & - & - & - & - \\
\hline Decreased & 0.091 & 0.045 & 0.055 & 0.021 & $-0.099^{\star}$ & -0.077 \\
\hline Constant & -0.031 & -0.001 & 0.003 & -0.002 & -0.014 & 0.021 \\
\hline Don't Know & 0.045 & $0.186^{\star \star \star}$ & 0.026 & 0.01 & -0.091 & 0.066 \\
\hline \multicolumn{7}{|l|}{ Exp. Change Firm } \\
\hline \multicolumn{7}{|l|}{ Emp. next Year } \\
\hline Increased (Reference) & - & - & - & - & - & - \\
\hline Decrease & $0.406^{\star \star \star}$ & $0.199^{\star \star \star}$ & $0.127^{\star \star \star}$ & 0.061 & $-0.12^{\star \star}$ & $-0.1 \star \star \star$ \\
\hline Constant & 0.056 & 0.036 & 0.005 & 0.044 & -0.004 & -0.051 \\
\hline Don't Know & $0.186^{\star \star \star}$ & $0.076^{\star}$ & 0.088 & $0.117^{\star \star \star}$ & -0.104 & -0.09 * \\
\hline \multicolumn{7}{|l|}{ Industry } \\
\hline Trade, Transport (Reference) & - & - & - & - & - & - \\
\hline Manuf., Agric. Energy & $0.112^{\star \star \star}$ & -0.048 & 0.025 & 0.03 & 0.005 & -0.04 \\
\hline Construction & 0.054 & 0.016 & 0.063 & $0.109^{\star \star}$ & 0.062 & $-0.179^{\star \star \star}$ \\
\hline Serv., Bank, Insur. & 0.029 & -0.068 & -0.057 & 0.018 & 0.065 & -0.027 \\
\hline Male & $-0.072^{\star \star}$ & -0.032 & $-0.065^{\star \star}$ & $-0.057^{\star \star}$ & 0.047 & $0.074^{\star \star}$ \\
\hline Unemployed last & $0.146^{\star \star \star}$ & $0.191^{\star \star \star}$ & $0.323^{\star \star \star}$ & $0.248^{\star \star \star}$ & 0.086 & 0.021 \\
\hline \multicolumn{7}{|l|}{12 month } \\
\hline Wage & $-0.087^{\star \star \star}$ & -0.018 & $-0.089^{\star \star \star}$ & -0.03 * & 0.009 & 0.024 \\
\hline Observations & 1871 & 945 & 1871 & 945 & 1871 & 945 \\
\hline
\end{tabular}

Note: Displayed coefficients are average marginal effects from logistic regression. Values for tenure, age, job changes and wage are standardized on a yearly basis. For readability, results for some control variables have been suppressed. The full list of control variables are: gender, education, state of residence, occupation, industry, indicators for the unemployment history, whether the worker lived in a urban or rural area, firm size, how the employment in her firm changed in the last 12 months and expectations about the change in the workforce in the next 12 months well as values for age, age ${ }^{2}$, wages, tenure in the industry and tenure in the firm standardized (by year). Significance: * Significant on the 10 percent level, ${ }^{* \star}$ Significant on the 5 percent level, ${ }^{* \star *}$ Significant on the 1 percent level.

Source: Own calculations based on the GSOEP.

Table 1 shows the changes in the average marginal effects of selected control variables for logistic regressions in 1991 and 1999, with dummy indicators for job loss expectations, real- 
ized future unemployment and accurate expectations as dependent variables. ${ }^{16}$ Significant discrepancies exist between the influences of some determinants on expectations and actual job loss. The most important example of this are expected changes in firm employment. If a worker expects that firm employment will decrease, the likelihood that she expects to lose her job is $41 \mathrm{pp}$ higher in 1991 compared to a worker who expects firm employment to increase (workers answering 'Don't Know' have a 19 pp higher probability). However, this difference does not correspond to a similar difference in the actual job loss risk (13 pp). The large effect on expectations also explains its aforementioned dominating role as a changing signal. ${ }^{17}$ When controlling for expected changes in firm employment, workers reporting different past changes in firm employment do not seem to show very different levels of job loss expectations or job loss risk. ${ }^{18}$

Among those expecting decreasing firm employment, job loss expectations fall strongly over time (-21 pp), whereas the reduction in the actual job loss risk is much smaller. In 1999, job loss expectations and realizations are much more similar than in 1991. This change over time could be driven by workers changing how they relate expected reductions in firm employment to their own job loss risk, for example because workers learn more about their individual job loss risk relative to their co-workers. However, it could also reflect changes in the size of the expected employment loss, due to the ambiguity of the question, as already discussed above. Most likely, both factors play a role in reducing the differences in job loss expectations. ${ }^{19}$ In any case, workers changed how they interpreted economic signals, be it through adapting their expectations about changes in firm employment or how they related these to their own job loss risk.

Other noteworthy findings are the following. Having been unemployed in the last 12 months strongly increases the likelihood of future unemployment by $32 \mathrm{pp}$. However, East German workers in 1991 seem to underestimate the link between recent and future unemployment, since recent unemployment shows a much smaller effect on job loss expectations than on job loss risk. The two factors converge to some extent, but remain different. Males are less likely to hold job loss expectations than females and their job loss risk falls short by about

\footnotetext{
16 We focus on the most important individual level determinants whose coefficients change by a substantial amount over time, as well as only discussing three of the outcome variables. Tables with all the coefficients for all the outcome variables are available upon request.

17 We chose expecting/reporting an increase in the workforce of one's firm as reference category, because job loss expectations and actual unemployment are quite stable over time in this category. Changes in average marginal effects could in principle be 'mechanically' driven by changes in the values of control variables. However, as Table 8 in the Appendix shows, changes in control variables do not significantly affect the values of average marginal effects, if coefficients are held constant at 1991 levels.

18 Table 9 in the Appendix shows results for regressions in which expected changes in firm employment are not used. It shows that past changes in firm employment largely pick up the effect of expected changes in firm employment, as well as firm size, which now has a significant effect on job loss expectations. Workers in larger firms are more likely to hold job loss expectations, which seems unjustified especially for workers in the largest firms.

19 Table 7 shows that the decline in the relative prevalence of job loss expectations in the group of workers who expected a reduction in firm employment was rather linear, whereas the economic situation stabilized already around 1992, indicating that the adaptation process of job loss expectations was rather gradual and not directly driven by economic fluctuations.
} 
the same amount. Higher wages on average are associated with both lower job loss expectations and lower actual job loss risk, and both effects fall over time. Furthermore, workers in manufacturing/agriculture/energy/mining more often expect job loss than workers in trade and transport in 1991, which is not reflected by the same variation in actual job loss risk. By 1999, industry affiliation does not affect expectations but workers in trade and transport have lower actual job loss risk.

Turning to expectation accuracy, the strong differences between the effects of determinants of job loss expectations and actual job loss should lead to lower expectation accuracy for different groups, especially for workers who expect a decrease in firm employment. Indeed, this group (which accounts for 60 percent of workers in 1991) shows a 12 pp lower expectation accuracy compared to the reference group, thus suggesting a key explanation for the low share of accurate expectations in 1991. However, the difference in accurate expectations between those expecting falling firm employment and other workers decreases only by a small amount over time despite the large drop in the relative level of job loss expectations in this group. Reasons for this are the changes in expectations for the reference group and in the composition of the samples in 1991 and 1999. Workers who expect falling firm employment are less often optimistic (-8 pp) and much more often pessimistic (+21 pp) than the reference group, which in turn causes the lower level of their (total) accurate expectations (Table 2). Over time, for both groups job loss expectations become more accurate (decreasing optimism or pessimism), thus limiting the change in the group difference. The decline in optimism is driven by panel attrition, since those dropping out of the panel between 1991 and 1999 are those who are especially optimistic when expecting an increasing workforce in their firm in 1991. Thus, the difference in accurate expectations across the different categories of expected changes in firm employment in 1991 as well as the change over time are much stronger in the balanced samples (Table 6 in the appendix). 
Table 2: Determinants of Correct Work, Correct Unemployment, Pessimism and Optimism in 1991 and 1999 in East Germany

\begin{tabular}{lcccc}
\hline Dependent Variable & \multicolumn{2}{c}{ Correct Work } & \multicolumn{2}{c}{ Correct Unemployment } \\
& 1991 & 1999 & 1991 & 1999 \\
\hline Change Firm Emp. & & & & \\
Previous Year & - & - & - & - \\
Increased (Reference) & $-0.101^{\star \star}$ & -0.069 & 0.036 & -0.004 \\
Decreased & 0.023 & 0.009 & -0.01 & 0.008 \\
Constant & -0.062 & -0.091 & -0.002 & $0.086^{\star \star}$ \\
Don't Know & & & & \\
\hline
\end{tabular}

\begin{tabular}{|c|c|c|c|c|}
\hline \multicolumn{5}{|l|}{ Exp. Change Firm } \\
\hline \multicolumn{5}{|l|}{ Emp. next Year } \\
\hline Increase (Reference) & - & - & - & - \\
\hline Decrease & $-0.303^{\star \star \star}$ & $-0.182^{\star \star \star}$ & $0.229^{\star \star \star}$ & $0.097^{\star \star \star}$ \\
\hline Constant & -0.021 & -0.065 & 0.036 & 0.006 \\
\hline Don't Know & $-0.16^{\star \star}$ & $-0.144^{\star \star \star}$ & $0.104^{\star \star \star}$ & 0.043 \\
\hline Observations & 1871 & 945 & 1871 & 908 \\
\hline \multirow[t]{2}{*}{ Dependent Variable } & \multicolumn{2}{|c|}{ Pessimistic } & \multicolumn{2}{|c|}{ Optimistic } \\
\hline & 1991 & 1999 & 1991 & 1999 \\
\hline \multicolumn{5}{|l|}{ Change Firm Emp. } \\
\hline \multicolumn{5}{|l|}{ Previous Year } \\
\hline Increased (Reference) & - & - & - & - \\
\hline Decreased & 0.082 & 0.033 & 0.02 & 0.032 \\
\hline Constant & 0.001 & -0.015 & 0.011 & -0.009 \\
\hline Don't Know & 0.053 & 0.083 & 0.024 & $-0.084^{\star \star \star}$ \\
\hline \multicolumn{5}{|l|}{ Exp. Change Firm } \\
\hline \multicolumn{5}{|l|}{ Emp. next Year } \\
\hline Increase (Reference) & - & - & - & - \\
\hline Decrease & $0.205^{\star \star \star}$ & $0.119^{\star \star \star}$ & $-0.083^{\star \star}$ & -0.019 \\
\hline Constant & 0.029 & 0.028 & -0.022 & 0.025 \\
\hline Don't Know & $0.106^{*}$ & 0.026 & 0.003 & 0.054 \\
\hline Observations & 1871 & 927 & 1871 & 945 \\
\hline
\end{tabular}

Note: Displayed coefficients are average marginal effects from logistic regression. Values for tenure, age, job changes and wage are standardized on a yearly basis. For readability, results for most control variables have been suppressed. The full list of control variables are: gender, education, state of residence, occupation, industry, indicators for the unemployment history, whether the worker lived in a urban or rural area, firm size, how the employment in her firm changed in the last 12 months and expectations about the change in the workforce in the next 12 months as well as values for age, age ${ }^{2}$, wages, tenure in the industry and tenure in the firm standardized (by year). Dependent Variables are defined in Section 4. Significance: * Significant on the 10 percent level, ${ }^{* *}$ Significant on the 5 percent level, ${ }^{* * *}$ Significant on the 1 percent level.

Source: Own calculations based on the GSOEP.

Similar to the findings above, workers in manufacturing/agriculture/energy show much higher job loss expectations in 1991 but a similar job loss risk compared to the reference group of workers in trade and transport, causing higher pessimism in this group. Again, the share of accurate expectations differs little, since workers in agriculture/energy/mining more often correctly predict job loss and are less often optimistic than the reference group. Over time, the level of accurate expectations relative to trade and transport workers drops in all industries, as accurate expectations increase strongly for workers in trade and transport. The lat- 
ter is driven by decreasing optimism in these industries - in this case not driven by sample attrition. In contrast, workers in construction become very (over)optimistic, apparently not foreseeing the decline in construction employment from the late 1990s onward.

In sum, the coefficients change considerably over time with regard to the probability of both job loss expectations and accurate expectations, which means that in addition to changing economic signals workers also adapt their interpretation of these signals. The latter is likely to be driven by learning processes with respect to the informational content of a signal, by better information about one's own personal job risk, and by a less pessimistic interpretation of signals. The adaptation of expectations reveals a strong heterogeneity across different groups.

\subsection{Convergence to West Germany}

We will now analyze the convergence between East and West Germany. We again use a nonlinear Oaxaca-Blinder-type decomposition for logit regressions analogous to the counterfactual analysis in Section 4.2. To do so, we predict the binary outcomes variables (job loss expectations and accurate expectations) for the counterfactual of West German signals and East German interpretation of signals. The difference between the average outcomes in the East and the counterfactual is the change in signals (endowments), whereas the average outcome in the West minus the counterfactual reflects the change in interpretations (coefficients). ${ }^{20}$

20 This decomposition could also be applied for changes within East Germany over time. However, then the problem arises how to separate the change in the intercept over time from changes in the other coefficients reflecting the interpretation of signals. We analyze convergence between East and West Germany based on evaluating differences between East and West in the same year. Here, convergence in coefficients is also meant to imply equalization of the intercept, which is reasonable when analyzing the degree of convergence between East and West Germany. 
Figure 12: Differences in Signals and Coefficients in East and West Germany

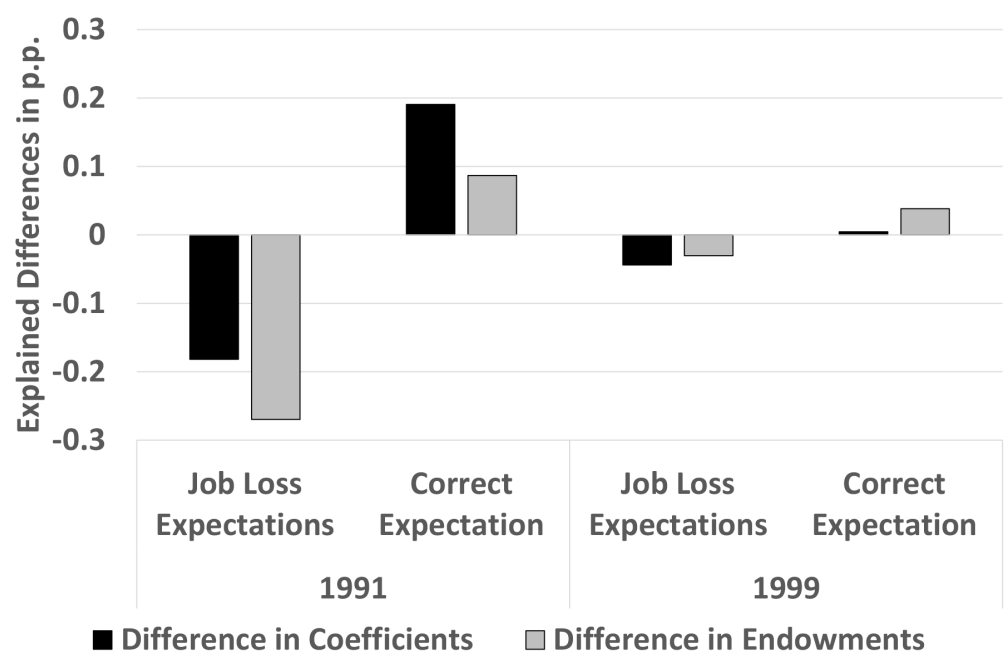

Note: The estimates are based on a non-linear Oaxaca-Blinder-Decomposition using a Logit Model and East Germany as the Reference Model. Displayed explained difference are the absolute amount of the difference in the outcome variable between East and West Germany by endowments and coefficients respectively.

Source: Own calculations based on the GSOEP.

Figure 12 shows the results of the decomposition between East Germany and West Germany in 1991 and 1999. The graph on the left shows that in 1991 the East-West differences in the shares of job loss expectations and accurate expectations are large and that both factors, differences in signals and coefficients, are important to explain those differences. The differences in signals prove more important for job loss expectations than for accurate expectations. In contrast, the East-West difference in job loss expectations and accurate expectations is very small in $1999 .{ }^{21}$ To allow for a more in-depth analysis, we further analyze the development of signals and coefficients with regard to past and expected changes in firm employment.

The East-West differences in past and expected changes firm employment in 1991 and 1999 are depicted in Figure 13. The 1991 figure shows substantial East-West differences. In contrast to the majority of East German workers expecting and reporting a rather dismal situation of their employer (64 percent), only 12 percent of West German workers expect their firm's employment to decrease, whereas 54 percent of workers in West Germany expect firm employment to remain constant and 21 percent expect an increase. The shares of reported past changes mirror these numbers. However, this changes completely in 1999. The discrepancies with respect to past and expected changes in firm employment basically vanish, showing a remarkable convergence between East and West Germany, which should explain a large part of the observed convergence.

21 When using East German signals and West German coefficients as counterfactual in the decomposition, the differences in coefficients explain a much higher share of overall differences in 1991 . This is due to the fact that the coefficients for the variables (signals) involving the strongest differences are much larger for East Germany, in particular regarding past/expected changes in firm employment. 
Figure 13: Differences in Shares of Expected and Past Firm Employment East-West 1991 and 1999

1991

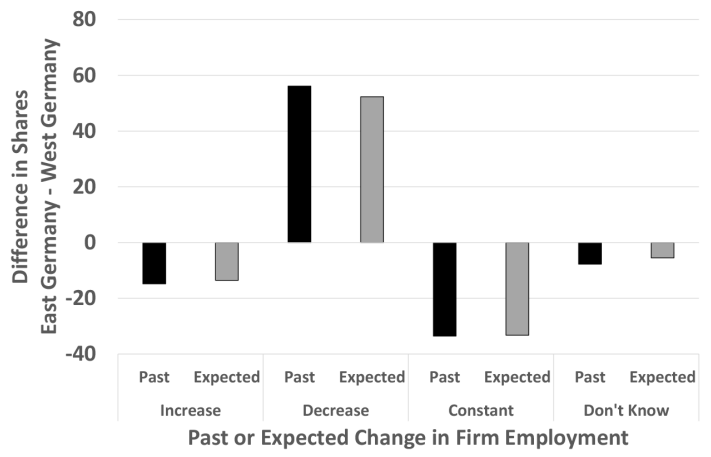

1999

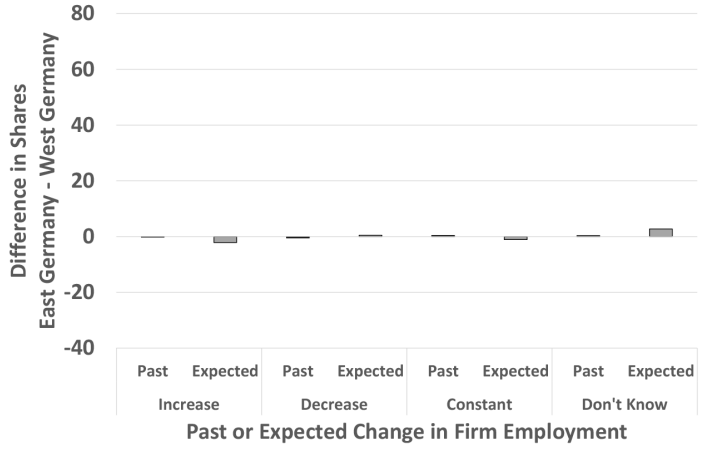

Note: Each bar in each category of expected/past changes in firm employment represents the difference between the share of workers that expect/report this change in firm employment in East German and West Germany in 1991 (left) and 1999 (right).

Source: Own calculations based on the GSOEP.

The shares of accurate expectations by categories of expected changes in firm employment also show convergence. The bars in Figure 14 display the differences in the average shares of accurate expectations in East and West Germany for each category of expected changes in firm employment in 1991 and 1999. The results show that in 1991, accurate expectations are on average lower for all workers in East Germany, irrespective of the expectation about changes in firm employment and considerably lower for those workers who expect a decrease in firm employment or don't know. In contrast, there exist only small differences conditional on expectations about firm employment in 1999.

Figure 14: Difference in Shares of Accurate expectations East/West in 1991/99 by Expected Changes in Firm Employment

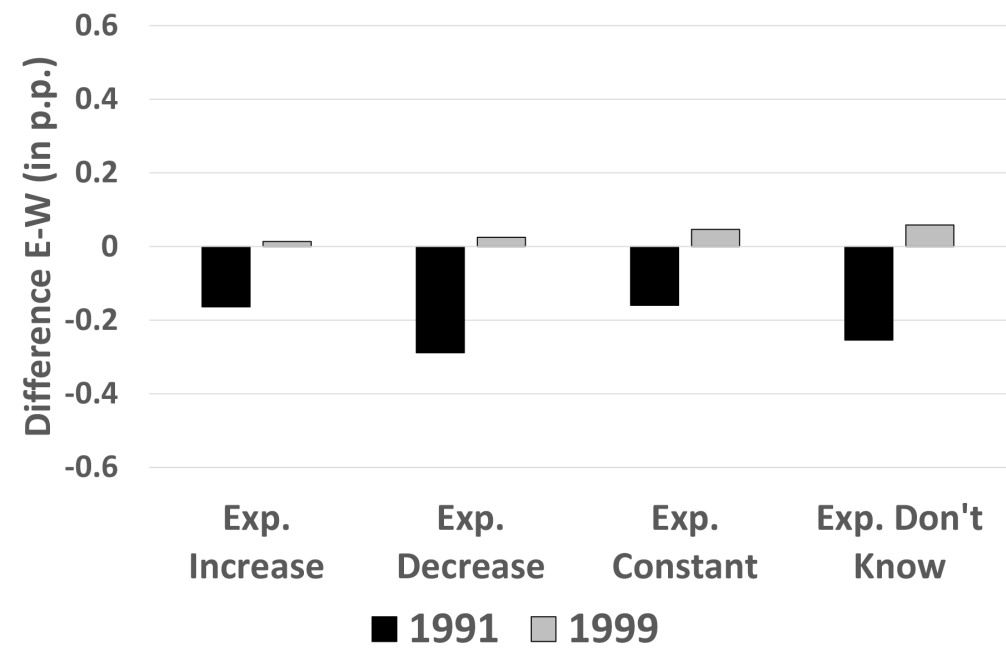

Note: Each bar in each expectation category represents the difference between the average of the shares of accurate expectations among workers in the specific catagory of expected changes in firm employment in East and West Germany for 1991 and 1999.

Source: Own calculations based on the GSOEP. 
Altogether, the economic situation as well as the interpretation of market signals in East Germany showed a remarkable convergence to West Germany, despite the remaining large economic differences between the two parts of the country (see Burda/Hunt (2001) for a discussion of the remaining differences).

\section{Robustness Checks}

\subsection{Involuntary Job Loss}

Until now, each transition to unemployment has been treated as a job loss. However, job termination might have different reasons, involving an (involuntary) lay-off, a voluntary termination of the contract by the worker or an expiration/annulment of a contract. ${ }^{22}$ The SOEP provides the reason of job termination for a substantial share of cases in East Germany (around 71 percent). Table 3 shows the shares of different reasons for job termination among all job losses (upper panel) and the share of job loss expectations among workers conditional on type of job loss/no job loss during the next two years (lower panel). The reported reasons concern the reason for the first job termination during the subsequent two years.

Table 3: Job Loss Expectations and Changes in Prevalence over Time for Different Types of Job Loss

\begin{tabular}{|c|c|c|c|c|c|}
\hline & \multicolumn{5}{|c|}{ Shares Types of Future Job Loss } \\
\hline & 1991 & 1992 & 1994 & 1996 & 1999 \\
\hline \multicolumn{6}{|l|}{ Reason Job Loss } \\
\hline Laid Off & $84.61 \%$ & $73.24 \%$ & $68.07 \%$ & $56.32 \%$ & $48.56 \%$ \\
\hline Voluntary Termination & $8.6 \%$ & $8.62 \%$ & $9.18 \%$ & $9.07 \%$ & $11.43 \%$ \\
\hline End Temporary Contract/Annulment Contract & $6.8 \%$ & $18.15 \%$ & $22.75 \%$ & $34.6 \%$ & $40.01 \%$ \\
\hline \multirow[t]{3}{*}{ Observations } & 384 & 250 & 172 & 164 & 127 \\
\hline & \multicolumn{5}{|c|}{ Share Job Loss Expectation by Type of Future Job Loss } \\
\hline & 1991 & 1992 & 1994 & 1996 & 1999 \\
\hline \multicolumn{6}{|l|}{ Reason Job Loss } \\
\hline Laid Off & $74.47 \%$ & $59.63 \%$ & $40.88 \%$ & $28.71 \%$ & $29.98 \%$ \\
\hline Voluntary Termination & $41.72 \%$ & $36.64 \%$ & $20.24 \%$ & $24.43 \%$ & $20.39 \%$ \\
\hline End Temporary Contract/Annulment Contract & $72.51 \%$ & $78.35 \%$ & $72.89 \%$ & $86.1 \%$ & $76.46 \%$ \\
\hline No Job Loss & $39.65 \%$ & $22.43 \%$ & $17.11 \%$ & $12.47 \%$ & $7.52 \%$ \\
\hline Observations & 1408 & 1229 & 1150 & 1001 & 844 \\
\hline
\end{tabular}

Note: Shares are based on workers who are employed in a given year. Reason for job loss refers to the reason of the first job loss in the next two years and 'No Job Loss' is true for workers who do not become unemployed within the next two years.

Source: Own calculations based on the GSOEP.

22 The latter two reasons can be distinguished in the SOEP, but in some years the two reasons are combined in the same answer category. Thus, we combine them in our analysis. 
The share of workers being laid-off among workers who become unemployed declines from 85 percent in 1991 to 49 percent in 1999, mostly due to an increase in the share of expiring of temporary contracts/annulment of contracts, whereas quits remain stable at $9-11$ percent. These changes are consistent with the strong transformation process in the early 1990s when many jobs were lost and the subsequent economic stabilization raising the share of less stable and temporary jobs. The shares in 1999 are close to the corresponding shares in West Germany. Job loss expectations differ strongly conditional on type of job loss/no job loss (see the lower part of Table 3). Before a job loss due to a temporary contract expiring or a contract annulment, workers had a constantly high likelihood of expecting job loss. Workers who quits their jobs themselves largely expected a job loss in 1991, but the share declines quickly over time and remains low. In case of lay-offs the share of job loss expectations amounted to 74 percent in 1991, suggesting that job losses due to lay-offs were actually easy to predict in that year. However, the share of job loss expectations for this group declines strongly to about 30 percent in 1999. This reflects a general downward trend in job loss expectations and a decline in the share of lay-offs that are easily predictable. Thus, workers in later years do not foresee a job termination under stable circumstances. Finally, the share of job loss expectations among those not losing their job falls from 40 percent in 1991 to 8 percent in 1999.

In sum, our findings show that job loss expectations differ by type of job loss. Nevertheless, when we focus on involuntary job losses only, the trends in job loss expectations in East Germany are very similar to the above findings for all job losses since most of the changes over time are driven by the decrease in pessimism.

\subsection{Additional Outcomes}

Next, we investigate if the patterns found for job loss expectations are also present for other subjective expectations about personal or general economic developments, and whether these assessments moderate the effect of our control variables on job loss expectations. The first set of outcomes involve worries about the future regarding the general economic situation, the personal situation, or the job security. The trend in worries is quite similar to that for job loss expectations. Nearly half of all workers report strong worries about the general economy or their job security in 1991 and 40 percent report strong worries about their own economic situation. In 1999, these figures drop to 26 percent for worries about the general economy, 19 percent for worries about the own situation and 24 percent for worries about job security. In a regression explaining job loss expectations, worries about the general economic situation or the own economic situation both show a positive association, while the coefficients of the other covariates remain basically unchanged. In particular, the strong effect of expecting a decline in firm employment is thus specific to job loss expectations and does not strongly affect other subjective assessments when the former is used as an outcomes vari- 
able in a logit regression. ${ }^{23}$ This also suggests that an expected decline in firm employment reflects the actual assessment of the economic situation of the firm rather than a general pessimism. Finally, the wording of the job loss question does not seem to drive our findings because individual level determinants have a similar effect on worries about job security as they have on job loss expectations (results are available upon request).

Table 4: Shares Additional Variables 1991 - 1999

\begin{tabular}{|c|c|c|c|c|c|}
\hline & \multicolumn{5}{|c|}{ Worries General Economic Situation } \\
\hline & 1991 & 1992 & 1994 & 1996 & 1999 \\
\hline Great Worries & $48.04 \%$ & $36.55 \%$ & $36.84 \%$ & $43.41 \%$ & $26.14 \%$ \\
\hline Some Worries & $46.92 \%$ & $56.04 \%$ & $59.26 \%$ & $53.25 \%$ & $70.3 \%$ \\
\hline No Worries & $5.04 \%$ & $7.41 \%$ & $3.9 \%$ & $3.33 \%$ & $3.55 \%$ \\
\hline \multirow[t]{3}{*}{ Observations } & 1866 & 1497 & 1311 & 1149 & 943 \\
\hline & \multicolumn{5}{|c|}{ Worries Own Economic Situation } \\
\hline & 1991 & 1992 & 1994 & 1996 & 1999 \\
\hline Great Worries & $40.16 \%$ & $30.55 \%$ & $22.57 \%$ & $20.44 \%$ & $19.23 \%$ \\
\hline Some Worries & $53.31 \%$ & $60.56 \%$ & $66.38 \%$ & $63.48 \%$ & $65.59 \%$ \\
\hline No Worries & $6.53 \%$ & $8.89 \%$ & $11.05 \%$ & $16.09 \%$ & $15.18 \%$ \\
\hline \multirow[t]{3}{*}{ Observations } & 1868 & 1498 & 1310 & 1147 & 944 \\
\hline & \multicolumn{5}{|c|}{ Worries Job Security } \\
\hline & 1991 & 1992 & 1994 & 1996 & 1999 \\
\hline Great Worries & $50.05 \%$ & $39.36 \%$ & $23.53 \%$ & $21.2 \%$ & $23.91 \%$ \\
\hline Some Worries & $36.1 \%$ & $41.24 \%$ & $52.04 \%$ & $48.16 \%$ & $54.54 \%$ \\
\hline No Worries & $13.85 \%$ & $19.4 \%$ & $24.43 \%$ & $30.64 \%$ & $21.54 \%$ \\
\hline \multirow[t]{3}{*}{ Observations } & 1841 & 1471 & 1294 & 1135 & 935 \\
\hline & \multicolumn{5}{|c|}{ Chance of Finding a Similar Position } \\
\hline & 1991 & 1992 & 1994 & 1996 & 1999 \\
\hline Easy & $7.97 \%$ & $13.33 \%$ & $12.48 \%$ & & $6.71 \%$ \\
\hline Difficult & $58.38 \%$ & $58.53 \%$ & $58.97 \%$ & & $67.47 \%$ \\
\hline Basically Impossible & $33.65 \%$ & $28.14 \%$ & $28.55 \%$ & & $25.83 \%$ \\
\hline Observations & 1867 & 1502 & 1310 & & 943 \\
\hline
\end{tabular}

Note: Shares are based on workers who are employed in a given year. The question for re-employability was not asked in 1996.

Source: Own calculations based on the GSOEP.

Next, we explore expected re-employment chances. Employed workers are asked how easy (easy, difficult, or basically impossible) it will be for them to find a job comparable to their current one in case of job loss (unfortunately, no such information is available for the unemployed). ${ }^{24}$ Surprisingly, re-employment expectations remain rather stable over time in East

${ }^{23}$ When the subjective assessment of the general or the workers own economic situation is used as an outcomes, workers expecting decreasing firm employment are $13 \mathrm{pp}$ more likely to have great worries about their own economic situation rather than some or no worries and the effect vanishes over time. The effects are insignificant with respect to the assessment of the general economic situation in 1991 or 1999.

24 Dickerson/Green (2012) use this question to analyze the accuracy of expectations by unemployed individuals. They find Germans workers (aggregating East and West) to be slightly optimistic, a finding being subject to the caveat that only employees are asked about this issue. Supporting the finding, Drahs/Haywood/Schiprowski (2018) report that unemployed workers are overoptimistic about their expected wage after re-employment. 
Germany, the share of 'easy' ('difficult') is 8 percent (58 percent) in 1991 and 7 percent (68 percent) in 1999, respectively. The share of 'basically impossible' is 34 percent in 1991 and 26 percent in 1999. Thus, the economic stabilization and the associated decline in expected job loss risk do not improve re-employment expectations. In West Germany, however, reemployment expectations worsen over time, which altogether leads to a convergence between East and West. In contrast to job loss expectations, re-employment expectations are not strongly influenced by the assessment of the economic situation of the firm. The share of workers answering 'easy' is about 3 pp lower in 1991 for workers who expect decreasing/constant employment in their firm compared to those expecting an increase in 1991 (4 pp lower for workers who answer 'difficult' to the re-employment question and thus is about $8 \mathrm{pp}$ higher for workers who answer 'basically impossible'). Even these small differences vanish by 1999 (detailed results are available upon request).

\section{Quality of Job Loss Prediction}

The convergence of East German job loss expectations towards West German levels is driven by a decline of job loss expectations among East German workers who expected job loss in the early 1990s but not actually lost their job in subsequent years (section 3). Still, the puzzle remains that the accuracy among those holding job loss expectations in the early 1990s was higher in East Germany than in West Germany, and the gap even increased until 1999, before it started to decline. Thus, surprisingly, one might think that in the 1990s job loss expectations among East German workers are more accurate than in West Germany. However, a simple explanation could be that the job loss rate is constantly higher in East Germany. To assess how the job loss rate among those expecting job loss in West Germany would change, if the job loss rate in West Germany were the same as in East Germany, we reweight the West German sample to create a sample that mirrors the East German sample with respect to the unemployment risk. To do so, we use estimated Inverse Probability Weights (IPW) based on regressing a region dummy on our unemployment indicator separately for each year (see Appendix A for a formal discussion).

Figure 15 shows job loss rates conditional on job loss expectations for workers in East Germany and for the reweighted sample in West Germany. For those not expecting job loss, the level differences between East and West Germany mostly vanish through reweighting and there is almost complete convergence from the mid 1990s onward - apart from year-to-year fluctuations in both curves for those expecting job loss. The unemployment rates for West German workers expecting job loss strongly increase through reweighting. Holding job loss risk constant, West Germans are actually quite accurate at predicting job loss in the early 1990s, and the rates are similar afterwards. Thus, differences in job loss risk are likely to ex- 
plain the rather surprising pattern visible in the unweighted sample of East German workers being constantly more accurate when holding job loss expectations. At the same time, the reweighting exercise cannot explain the increasing and then decreasing accuracy in expectations in East Germany among workers who hold job loss expectations. ${ }^{25}$

\section{Figure 15: Realized Unemployment Conditional on Job Loss Expectations after Reweighting}

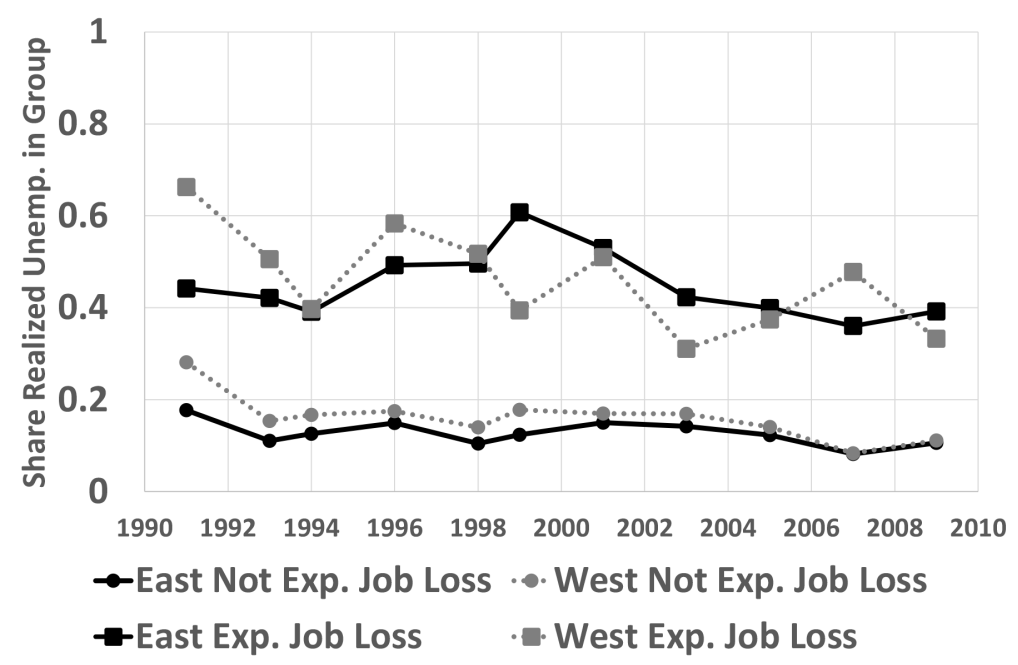

Note: Displayed results for West Germany are based on a sample that has been reweighted to mirror the distribution of the likelihood of job loss in East Germany. Displayed shares are the weighted averages of the outcome variables in West Germany, separately for the group that expects job loss and for those who do not expect job loss, using the estimated IPW as weights, whereas the results for East Germany are not based on reweighting.

Source: Own calculations based on the GSOEP.

Part of the fluctuations among those expecting job loss in East Germany can be explained by the changing structure of the reasons for job termination and by composition effects. As discussed above, an increasing share of workers who expect job loss are workers who correctly do so because they predict the future expiration/annulment of their contract. This increases the rate of job loss among those expecting to lose their job and thus the accuracy of job loss expectations among these workers over time. Figure 16 shows the job loss rate for workers, when only lay-offs are considered. The job loss rate for East German workers expecting job loss is now much more stable over time (apart from a drop in 2007), indicating no strong change in the accuracy over time when only lay-offs are considered. ${ }^{26}$ Furthermore, the decline in the overall job loss rate for workers who expect job loss after 1999 is driven by the

25 The developments are not driven by sample attrition, because the findings for different samples, for example conditioning on not dropping out of the SOEP between 1991 and 1999 or 2009, all show similar developments. Detailed results are available upon request.

26 The comparison of East and West Germany when only involuntary job losses are considered shows quite similar findings to the case when all job losses are considered. However, in the West German sample only for 50 percent of job losses a reason is available and involuntary job losses only make up around 45 percent of job losses for which a reason is reported. 
larger share of workers changing from no job loss expectations to expecting job loss among all workers who expect job loss. This group shows a lower job loss rate than other workers with job loss expectations.

Figure 16: Realized Unemployment through Lay-offs Conditional on Job Loss Expectations

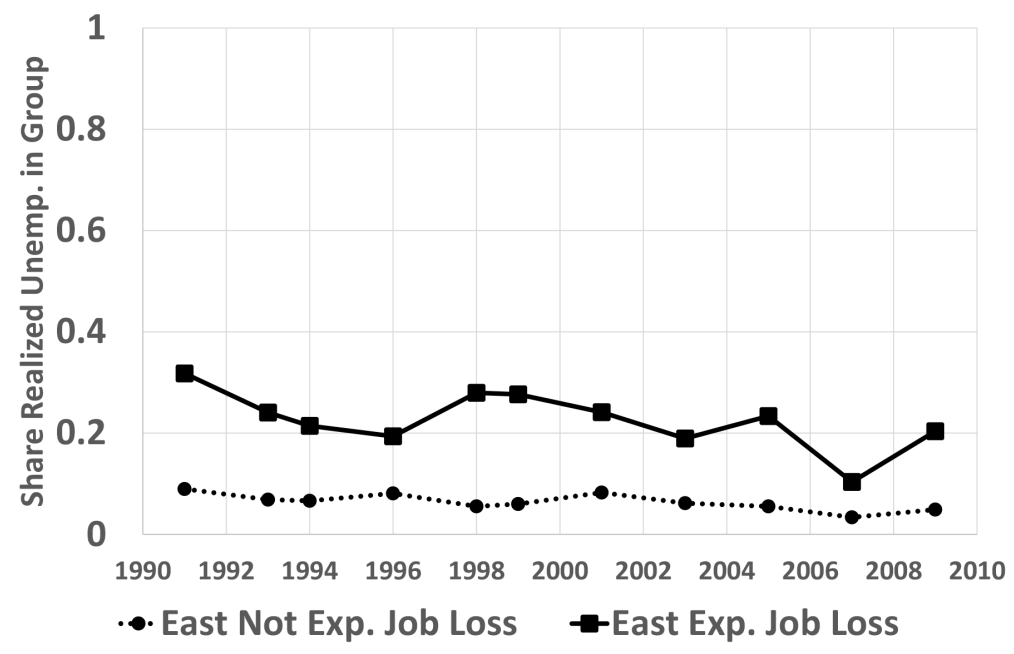

Note: Displayed are job loss rates for the group of East German workers that expects job loss and for the group who does not expect job loss. In contrast to before, only job loss through a lay-off is counted as job loss.

Source: Own calculations based on the GSOEP.

\section{Conclusions}

Our findings show that a large negative economic shock, like the reunification shock in East Germany, can strongly distort job loss expectations leading to strong overpessimism with 30 percent of workers expecting job loss and actually not losing their jobs in the early 1990s. Since various studies point to the negative effect of job loss expectation on individual level outcomes, such an economic shock might have strong effects on these outcomes (like wellbeing, job security or wage growth) through the channel of job loss expectations. However, our results also demonstrate that the stabilization of the economic situation and the adaptation of expectations through changing interpretations of economic signals strongly reduces job loss expectations and (over)pessimism over time. Comparing the outcomes for East and West Germany shows that within a decade job loss expectations converged to a remarkable extent between the two parts of the country. Further, we find that in (stable) market economies rather the assessment of the economic situation of a worker's firm is the key driver of job loss expectations and not the assessment of the situation of the entire economy. When both controls are used together in a regression explaining job loss expectations, greater worries about the general economic situation have a much weaker impact than expecting a fall in firm employment. 
The convergence of job loss expectations in East Germany over the 1990s to West German levels limits adverse long-term effects of the strong initial overpessimism after reunification. However, even in the 2000s there still exists a difference in the share of workers being sure not to lose their job between East and West Germany. This suggests some lasting adverse effects on individual outcomes of the employment uncertainty as perceived by many East Germans in the years after reunification, even long after economic conditions have stabilized.

A more extensive analysis of the scarring effects of experiencing a period of strong economic uncertainty and overpessimism, as documented in the literature for the influence of recessions on preferences and risk taking later in life (Giuliano/Splimbergo (2014),Malmendier/ Nagel (2011)) as well as on inflation expectations in East Germany Goldfayn-Frank/Wohlfart (2020)), is a promising area for future research. Furthermore, future research should analyze if similar patterns as found for East Germany after reunification also apply in other settings where individuals experience a large negative economic shock, for example in declining industries or regions with mass lay-offs and high economic uncertainty. 


\section{References}

Aaronson, Daniel (1998): The decline of job security in the 1990s. In: Economic Perspectives, Vol. 22, No. 1, p. 17-43.

Armantier, Olivier; Topa, Giorgio; van der Klaauw, Wilbert; Zafar, Basit (2016): The Price Is Right: Updating Inflation Expectations in a Randomized Price Information Experiment. In: The Review of Economics and Statistics, Vol. 98, No. 3, p. 503-523.

Benito, Andrew (2006): Does job insecurity affect household consumption? In: Oxford Economic Papers, Vol. 58, No. 1, p. 157-181.

Bernardi, Laura; Klärner, Andreas; Lippe, Holger (2008): Job insecurity and the timing of parenthood. In: European Journal of Population, Vol. 24, No. 3, p. 287-313.

Bohle, Philip; Quinlan, Michael; Mayhew, Claire (2001): The health and safety effects of job insecurity. In: The Economic and Labour Relations Review, Vol. 12, No. 1, p. 32-60.

Burchell, Brendan; Ladipo, David; Wilkinson, Frank (Eds.) (2002): Job insecurity and work intensification. Routledge studies in employment relations, London [u.a.]: Routledge.

Burda, Michael C.; Hunt, Jennifer (2001): From Reunification to Economic Integration: Productivity and the Labor market in Eastern Germany. In: Brookings Papers on Economic Activity, Vol. 32, No. 2, p. 1 - 92.

Campbell, David; Carruth, Alan; Dickerson, Andrew; Green, Francis (2007): Job insecurity and wages. In: The Economic Journal, Vol. 117, No. 518, p. 544-566.

Carroll, Christopher D.; Dynan, Karen E.; Krane, Spencer D. (2003): Unemployment risk and precautionary wealth. In: The Review of Economics and Statistics, Vol. 85, No. 3, p. 586604.

Chawla, Nitesh V.; Bowyer, Kevin W.; Hall, Lawrence O.; Kegelmeyer, W. Philipp (2002): SMOTE: Synthetic Minority Over-sampling Technique. In: Journal of Artificial Intelligence Research, Vol. 16, p. 231-357.

Coibion, Olivier; Gorodnichenko, Yuriy; Kamdar, Rupal (2018): The formation of expectations, inflation and the Phillips curve. In: Journal of Economic Literature, Vol. 56, No. 4, p. 14471491.

Dickerson, Andy; Green, Francis (2012): Fears and realisations of employment insecurity. In: Labour Economics, Vol. 19, No. 2, p. 198-210.

Dominitz, Jeff; Manski, Charles F. (1997): Perceptions of Economic Insecurity: Evidence From the Survey of Economic Expectations. In: The Public Opinion Quarterly, Vol. 61, No. 2, p. 261-287. 
Drahs, Sascha; Haywood, Luke; Schiprowski, Amelie (2018): Job search with subjective wage expectations. In: CRC Transregio 190, DP No. 75.

Elman, Cheryl; O'Rand, Angela M. (2002): Perceived job insecurity and entry into work-related education and training among adult workers. In: Social Science Research, Vol. 31, No. 1, p. 49-76.

Fairlie, Robert W. (1999): The absence of the African-American owned business: An Analysis of the Dynamics of Self-Employment. In: Journal of Labor Economics, Vol. 17, No. 1, p. 80-108.

Giuliano, Paola; Splimbergo, Antonio (2014): Growing up in a recession. In: The Review of Economic Studies, Vol. 81, No. 2, p. 787-817.

Goldfayn-Frank, Olga; Wohlfart, Johannes (2020): Expectation formation in a new environment: Evidence from the German reunificiation. In: Journal of Monetary Economics, Vol. 115, p. $301-320$.

Green, Francis (2011): Unpacking the misery multiplier. In: Journal of Health Economics, Vol. 30, No. 2, p. 265-276.

Green, Francis; Felstead, Alan; Burchell, Brendan (2000): Job insecurity and the difficulty of regaining employment. In: Oxford Bulletin of Economics and Statistics, Vol. 62, No. s1, p. 855-883.

Huber, Martin; Lechner, Michael; Wunsch, Conny (2013): The performance of estimators based on the propensity score. In: Journal of Econometrics, Vol. 175, No. 1, p. 1-21.

Kassenböhmer, Sonja C.; Schatz, Sonja G. (2017): Re-employment expectations and realisations: Prediction errors and behavioural responses. In: Labour Economics, Vol. 44, p. 161-176.

Knabe, Andreas; Rätzel, Steffen (2010): Better an insecure job than no job at all? Unemployment, job insecurity and subjective wellbeing. In: Economics Bulletin, Vol. 30, No. 3, p. 2486-2494.

Kučinskas, Simas; Peters, Florian S. (2018): Measuring Biases in Expectation Formation. In: Tinbergen Institute Discussion Paper TI 2018-058/IV.

Lechner, Michael; Pfeiffer, Friedhelm; Wagner, Gert G. (1994): Labour market dynamics and employee expectations in East Germany following reunification. In: Vierteljahrshefte zur Wirtschaftsforschung, Vol. 63, No. 1/2, p. 75-80.

Liepmann, Hannah (2018): The impact of a negative labor demand shock on fertility - Evidence from the fall of the Berlin Wall. In: Labour Economics, Vol. 54, p. 210-224.

Linz, Susan J.; Semykina, Anastasia (2008): How do workers fare during transition? In: Labour Economics, Vol. 15, No. 3, p. 442-458. 
Lübke, Christiane; Erlinghagen, Marcel (2014): Self-perceived job insecurity across Europe over time: Does changing context matter? In: Journal of European Social Policy, Vol. 24, No. 4, p. $319-336$.

Lusardi, Annamaria (1998): On the importance of the precautionary saving motive. In: The American Economic Review, Vol. 88, No. 2, p. 449-453.

Malmendier, Ulrike; Nagel, Stefan (2016): Learning from Inflation Experiences. In: The Quarterly Journal of Economics, Vol. 131, No. 1, p. 53-87.

Malmendier, Ulrike; Nagel, Stefan (2011): Depression babies. In: The Quarterly Journal of Economics, Vol. 126, No. 1, p. 373-416.

Manski, Charles F. (2004): Measuring expectations. In: Econometrica, Vol. 72, No. 5, p. 13291376.

Manski, Charles F.; Straub, John D. (2000): Worker perceptions of job insecurity in the mid1990s. In: Journal of Human Resources, Vol. 35, No. 3, p. 447-479.

Probst, Tahira M.; Brubaker, Ty L. (2001): The Effects of Job Insecurity on Employee Safety Outcomes: Cross-Sectional and Longitudinal Explorations. In: Journal of Occupational Health Psychology, Vol. 6, No. 2, p. 139-159.

Roth, Christopher; Wohlfart, Johannes (2020): How Do Expectations about the Macroeconomy Affect Personal Expectations and Behavior? In: Review of Economics and Statistics, Vol. 102, No. 4, p. $731-748$.

Schmidt, Stefanie R. (1999): Long-run trends in workers' beliefs about their own job security. In: Journal of Labor Economics, Vol. 17, No. S4, p. 127-141.

Sinning, Mathias; Hahn, Markus; Bauer, Thomas K. (2008): The Blinder-Oaxaca decomposition for nonlinear regression models. In: The Stata Journal, Vol. 8, No. 4, p. 480 - 492.

Stephens, Melvin (2004): Job loss expectations, realizations, and household consumption behavior. In: The Review of Economics and Statistics, Vol. 86, No. 1, p. 253-269.

Sverke, Magnus; Goslinga, Sjoerd (2003): The Consequences of Job Insecurity for Employers and Unions: Exit, Voice and Loyalty. In: Economic and Industrial Democracy, Vol. 24, No. 2, p. 241-270.

Tortorice, Daniel Louis (2012): Unemployment expectations and the business cycle. In: The B.E. Journal of Macroeconomics, Vol. 12, No. 1, p. 1-47.

Warr, Peter Bryan (1987): Work, unemployment and mental health. Oxford science publications, Oxford [u.a.]: Clarendon Press.

Wichert, Ines C.; Nolan, Jane P.; Burchell, Brendan J. (2000): Workers on the edge. Washington, DC: Economic Policy Institute. 


\section{Appendix}

\section{A. Inverse Probability Weights}

IPW is used to balance the observable characteristics between East and West Germany. Since we reweight towards the distribution of characteristics in East Germany, East German workers get a weight of 1 and we reweight West Germany such that the distribution of job loss risk mimics the one among East Germans. To obtain the weights for West Germany, we estimate a logit model for each year with the region dummy as dependent variable and our indicator for future unemployment as control variable. The estimated propensity scores, $\hat{p}\left(X_{i}\right)$, are used to compute the normalized weights for a West German individual $j$ using the following formula

$\hat{w}_{i}^{y}=\frac{\frac{\hat{p}\left(X_{j}\right)}{1-\hat{p}\left(X_{j}\right)}}{\sum_{i \in N_{y}}\left(1-T_{i}\right) \frac{\hat{p}\left(X_{i}\right)}{1-\hat{p}\left(X_{i}\right)}}$

where $T_{i}$ is an indicator which is equal to $1(0)$ if individual $i$ is East Germany (West Germany) and $N_{y}$ are all individuals observed in year $c$. Individuals with too large weights are discarded from the computation of the ATT, based on the method described in Huber/Lechner/Wunsch (2013). For the reweighted shares in West Germany in year $y, \frac{1}{\sum_{i \in N_{y}} \hat{w}_{i}^{c}} \sum_{i \in N_{y}} \hat{w}_{i}^{c} Y_{i}$ is computed where $Y_{i}$ is an the indicator variable for holding job loss expectations, future unemployment or a specific expectation-realization pair. 


\section{B. Figures}

Figure 17: Shares and Actual Unemployment for Disaggregated Job Loss Expectation Indicator

1991

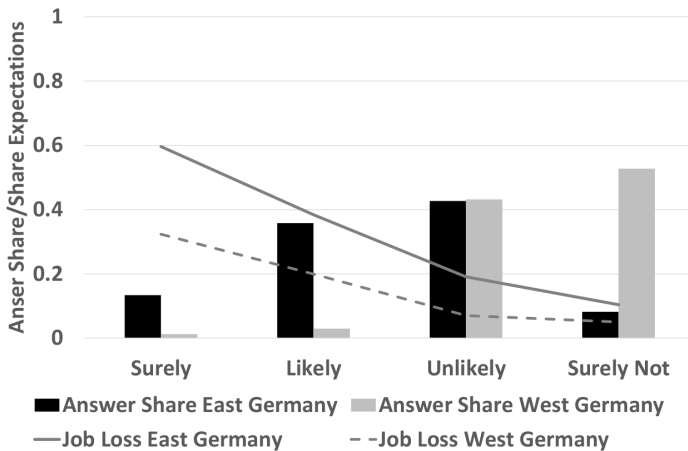

1996

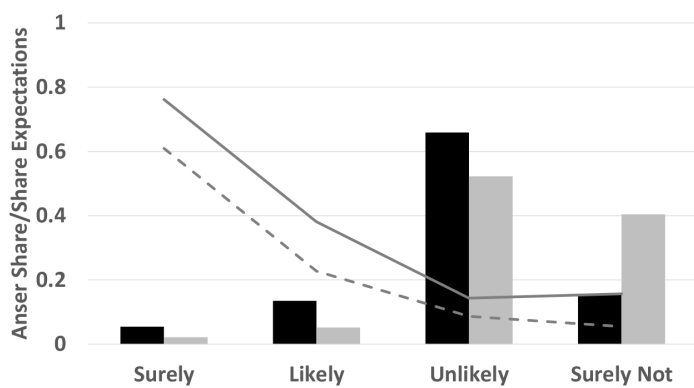

-Answer Share East Germany Answer Share West Germany —Job Loss East Germany

- -Job Loss West Germany
1993

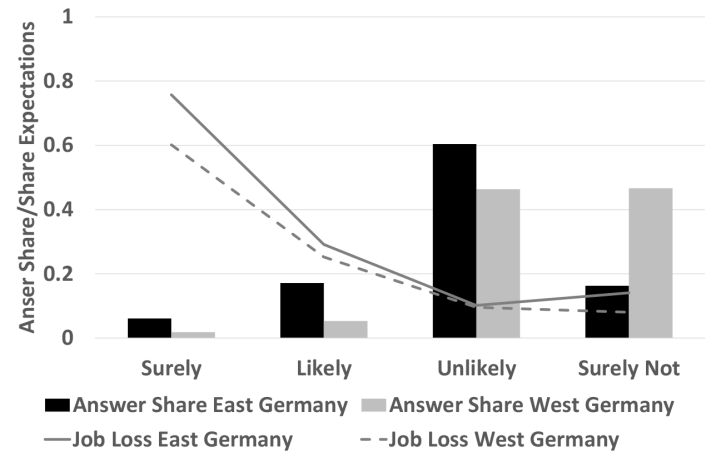

1998

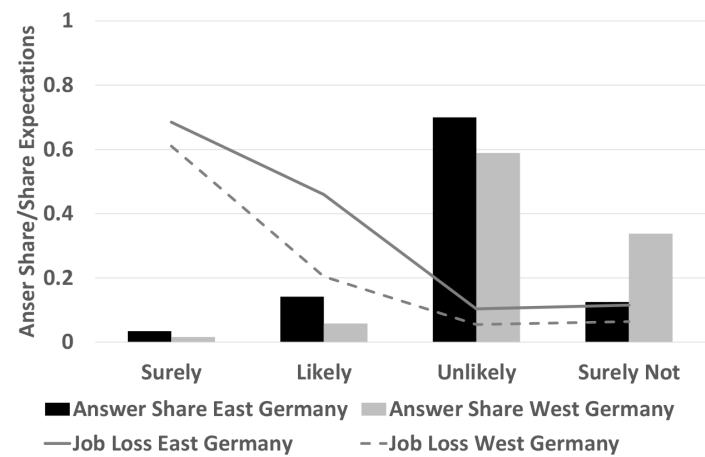

Note: The graphs show the shares of for the different answers to the job loss question and actual job loss in the coming two years among all workers in the sample in a specific year.

Source: Own calculations based on the GSOEP. 
Figure 18: Predictive Power of Changes in Endowments Across Different Samples

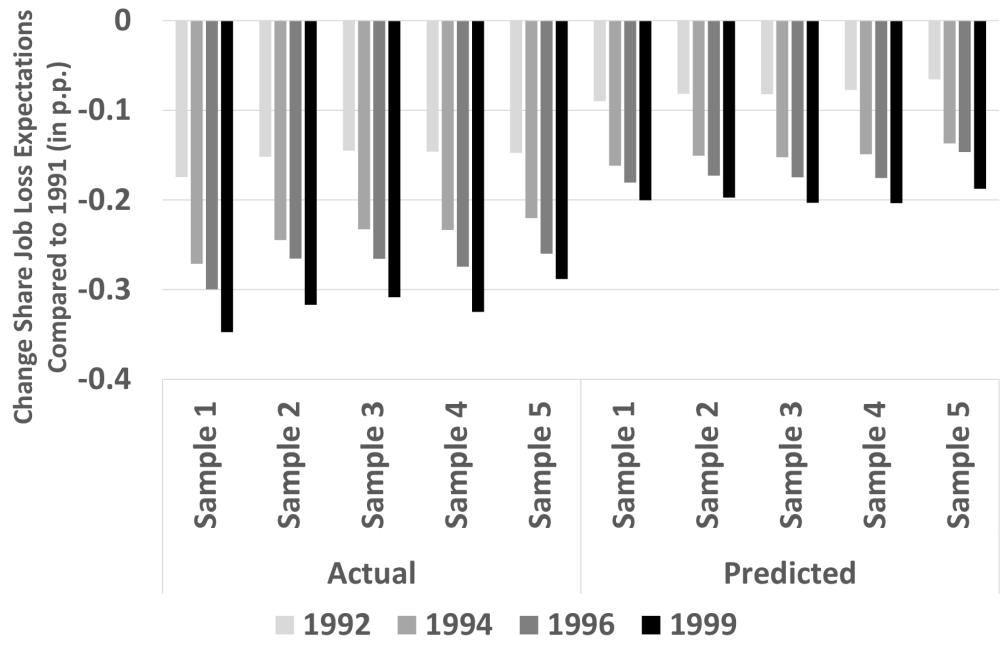

Note: The graphs are obtained by first predicting the value of the correct expectation dummy for each worker and in each year, based on coefficients from a logistic regression using data from 1991 and different sample definitions. Shares are the averages of these predicted values across all workers. This is contrasted with the actual changes in the share of accurate expectations. The displayed shares are the differences in pp compared to the shares in 1991. Sample 1 is defined as all observations who already worked in the GDR, are less than 60 years old and have no missing values for any of the control variables. Sample 2 then requires workers to not have dropped out of the GSOEP between 1991 and 1999. Sample 3 additionally deletes all (past and future) East Germany migrants to West Germany. Sample 4 additionally excludes all individuals who have missing values in at least one control variable in 1991 and 1999. Sample 5 then additionally requires that a worker is employed in both 1991 and 1999.

Source: Own calculations based on the GSOEP. 
Figure 19: Predictive Power of Changes in Endowments for Job Loss Expectations for different Reference Years

1

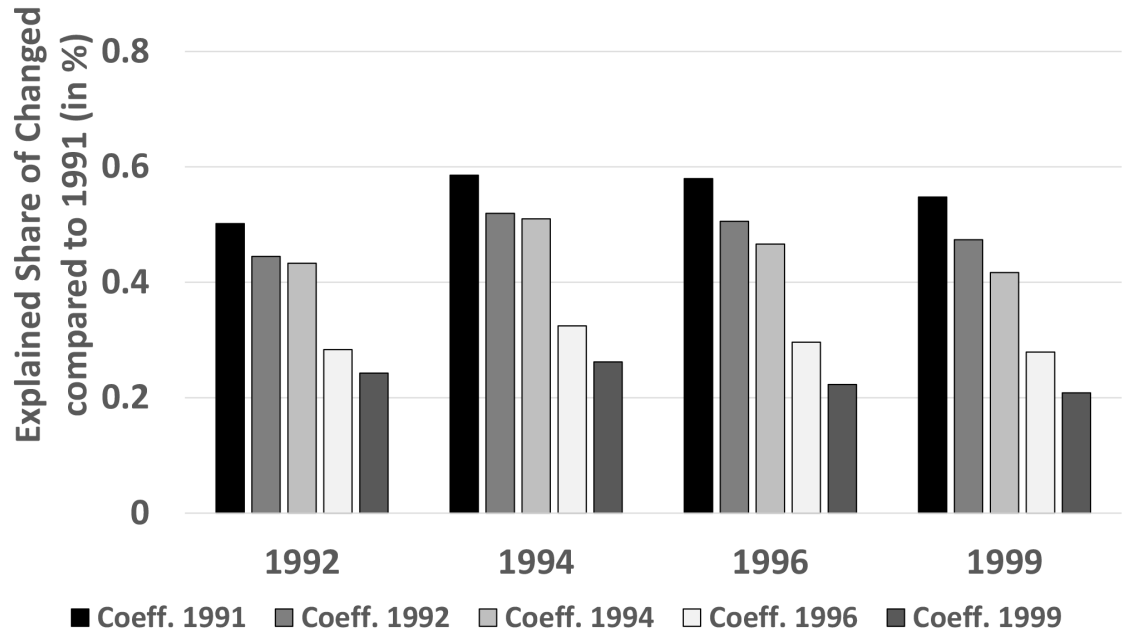

Note: The graphs are obtained by first predicting the value of the job loss expectation dummy for each worker and in each year, based on coefficients from a logistic regression using data from 1991, 1992, 1994, 1996 or 1999 separately. The explained shares is then the difference in the average predicted share in a given year and the predicted value in 1991 divided by the actual difference between the share of job loss expectations in a given year and 1991. Formally this means ExpShare $t=\frac{\frac{1}{N_{t}} \sum_{i}^{N_{t}} \hat{\operatorname{Pr}} r\left(y_{i, t}=1 \mid X_{i, t}, \beta_{k}\right)-\frac{1}{N_{9} 1} \sum_{i}^{N_{9} 1} \hat{\operatorname{Pr}} r\left(y_{i, 91}=1 \mid X_{i, 91}, \beta_{9} 1\right)}{\frac{1}{N_{t}} \sum_{i}^{N_{t}} \operatorname{Exp}_{i, t}-\frac{1}{N_{9} 1} \sum_{i}^{N_{9}{ }^{1}} \operatorname{Exp} p_{i, 91}}$ where $\operatorname{Exp}_{i, t}$ is a dummy for expecting job loss in year tand $t=1991,1992,1994,1996$ or 1999. Source: Own calculations based on the GSOEP. 
Figure 20: Predictive Power of Changes in Endowments without Exp. Changes in Firm Employment

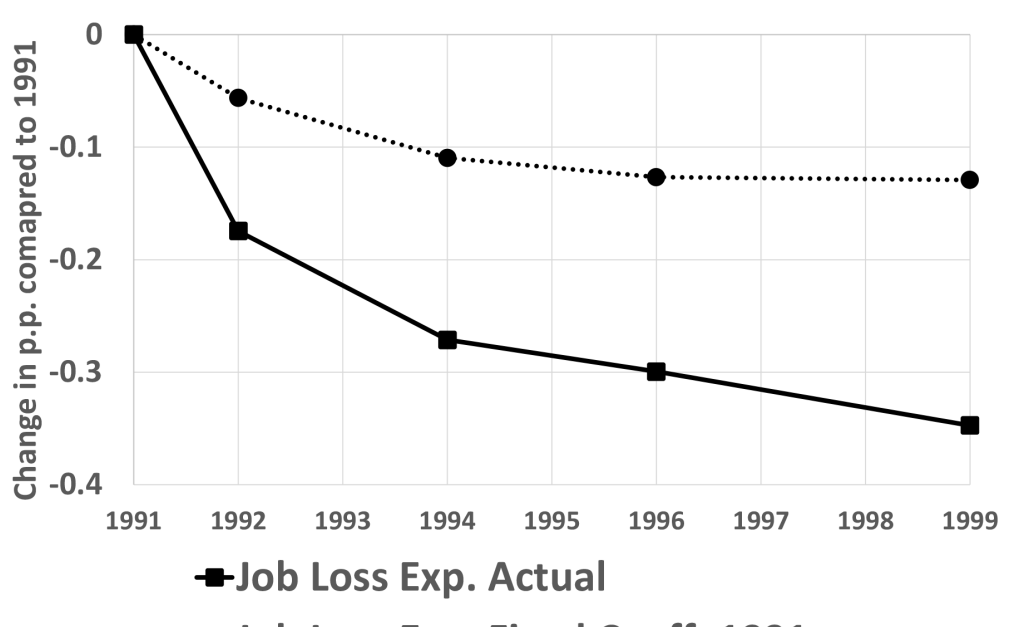

- Job Loss Exp. Fixed Coeff. 1991

Note: The graphs are obtained by first predicting the value of the correct expectation dummy for each worker and in each year, based on coefficients from a logistic regression using data from 1991. Shares are the averages of these predicted values across all workers. This is contrasted with the actual changes in the share of accurate expectations. The displayed shares are the differences in pp compared to the shares in 1991 (left).

Source: Own calculations based on the GSOEP. 


\section{Tables}

Table 5: Confusion Matrix

\begin{tabular}{ccc} 
& Expect Job Loss $=$ No & Expect Job Loss $=$ Yes \\
\hline Actual Job Loss $=$ No & $\begin{array}{c}\text { True Negative } \\
\text { 'Correct Work' }\end{array}$ & $\begin{array}{c}\text { False Positive } \\
\text { 'Pessimistic' }\end{array}$ \\
\hline Actual Job Loss = Yes & $\begin{array}{c}\text { False Negative } \\
\text { 'Optimistic' }\end{array}$ & $\begin{array}{c}\text { True Positive } \\
\text { 'Correct UE' }\end{array}$
\end{tabular}


Table 6: Determinants of Job Loss Expectations, Unemployment and Accurate Expectations in Different Samples in 1991

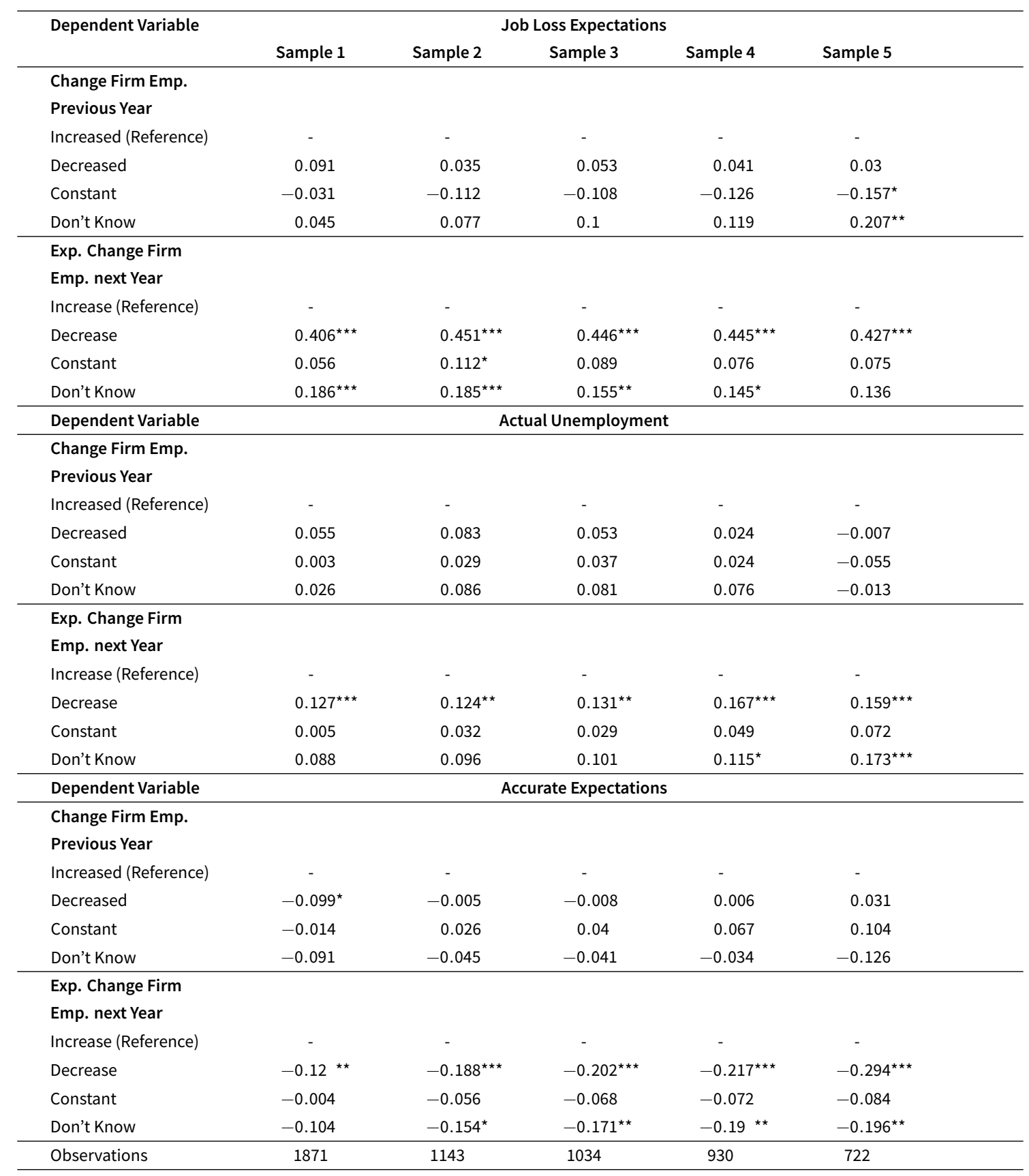

Note: Displayed coefficients are average marginal effects from logistic regression. Values for tenure, age, job changes and wage are standardized on a yearly basis. For readability, results for some control variables have been suppressed. The full list of control variables are: gender, education, state of residence, occupation, industry, indicators for the unemployment history, whether the worker lived in a urban or rural area, firm size, how the employment in her firm changed in the last 12 months and expectations about the change in the workforce in the next 12 months as well as values for age, age ${ }^{2}$, wages, tenure in the industry and tenure in the firm standardized (by year). Sample 1 is defined as all observations who already worked in the GDR, are less than 60 years old and have no missing values for any of the control variables. Sample 2 then requires workers to not have dropped out of the GSOEP between 1991 and 1999. Sample 3 additionally deletes all (past and future) East Germany migrants to West Germany. Sample 4 additionally excludes all individuals who have missing values in at least one control variable in 1991 and 1999. Sample 5 then additionally requires that a worker is employed in both 1991 and 1999 . Significance: * Significant on the 10 percent level, ${ }^{\star *}$ Significant on the 5 percent level, ${ }^{\star \star *}$ Significant on the 1 percent level.

Source: Own calculations based on the GSOEP. 
Table 7: Determinants of Job Loss Expectations for all Years

\begin{tabular}{|c|c|c|c|c|c|}
\hline \multirow[t]{2}{*}{ Dependent Variable } & \multicolumn{5}{|c|}{ Job Loss Expectations } \\
\hline & 1991 & 1992 & 1994 & 1996 & 1999 \\
\hline \multicolumn{6}{|l|}{ Change Firm Emp. } \\
\hline \multicolumn{6}{|l|}{ Previous Year } \\
\hline Increased (Reference) & - & - & - & - & - \\
\hline Decreased & 0.091 & $0.093^{\star \star}$ & $0.125^{\star \star \star}$ & 0.067 & 0.045 \\
\hline Constant & -0.031 & -0.029 & 0.027 & 0.006 & -0.001 \\
\hline Don't Know & 0.045 & 0.052 & 0.12 * & 0.014 & $0.186^{\star \star \star}$ \\
\hline \multicolumn{6}{|l|}{ Exp. Change Firm } \\
\hline \multicolumn{6}{|l|}{ Emp. next Year } \\
\hline Increase (Reference) & - & - & - & - & - \\
\hline Decrease & $0.406^{\star \star \star}$ & $0.386^{\star \star \star}$ & $0.296^{\star \star \star}$ & $0.278^{\star \star \star}$ & $0.199^{\star \star \star}$ \\
\hline Constant & 0.056 & $0.069^{\star \star}$ & 0.032 & 0.03 & 0.036 \\
\hline Don't Know & $0.186^{\star \star \star}$ & $0.175^{\star \star \star}$ & $0.218^{\star \star \star}$ & $0.147^{\star \star}$ & $0.076^{\star}$ \\
\hline Observations & 1871 & 1504 & 1313 & 1149 & 945 \\
\hline \multicolumn{6}{|c|}{$\begin{array}{l}\text { Note: Displayed coefficients are average marginal effects from logistic regression. Values for tenure, age, job changes and wage are } \\
\text { standardized on a yearly basis. For readability, results for some control variables have been suppressed. The full list of control vari- } \\
\text { ables are: gender, education, state of residence, occupation, industry, indicators for the unemployment history, whether the worker } \\
\text { lived in a urban or rural area, firm size, how the employment in her firm changed in the last } 12 \text { months and expectations about the } \\
\text { change in the workforce in the next } 12 \text { months as well as values for age, age }{ }^{2} \text {, wages, tenure in the industry and tenure in the firm } \\
\text { standardized (by year). Significance: }{ }^{\star} \text { Significant on the } 10 \text { percent level, }{ }^{\star *} \text { Significant on the } 5 \text { percent level, }{ }^{\star \star \star ~ S i g n i f i c a n t ~ o n ~ t h e ~} 1 \\
\text { percent level. }\end{array}$} \\
\hline
\end{tabular}

Source: Own calculations based on the GSOEP. 
Table 8: Average Marginal Effects Based on 1991 Coefficients

\begin{tabular}{|c|c|c|c|c|c|}
\hline & \multicolumn{5}{|c|}{ Job Loss Expectations } \\
\hline & 1991 & 1992 & 1994 & 1996 & 1999 \\
\hline \multicolumn{6}{|l|}{ Exp. Change Firm } \\
\hline \multicolumn{6}{|l|}{ Emp. next Year } \\
\hline Increase (Reference) & - & - & - & - & - \\
\hline Decrease & $0.406^{\star \star \star}$ & $0.398^{\star \star \star}$ & $0.389^{\star \star \star}$ & $0.385^{\star \star \star}$ & $0.389^{\star \star \star}$ \\
\hline Constant & 0.056 & 0.053 & 0.05 & 0.048 & 0.049 \\
\hline Don't Know & $0.186^{\star \star \star}$ & $0.178^{\star \star \star}$ & $0.169^{\star \star \star}$ & $0.165^{\star \star \star}$ & $0.168^{\star \star \star}$ \\
\hline \multicolumn{6}{|l|}{ Industry } \\
\hline Trade, Transport (Reference) & - & - & - & - & - \\
\hline Manuf., Agric. Energy & $0.112^{\star \star \star}$ & $0.104^{\star \star \star}$ & $0.1^{\star \star \star}$ & $0.101^{\star \star \star}$ & $0.1^{\star \star \star}$ \\
\hline Construction & 0.054 & 0.05 & 0.047 & 0.047 & 0.046 \\
\hline Serv., Bank, Insur. & 0.029 & 0.027 & 0.025 & 0.025 & 0.025 \\
\hline Male & $-0.072^{\star \star}$ & $-0.068^{\star \star}$ & $-0.066^{\star \star}$ & $-0.067^{\star \star}$ & $-0.067^{\star \star}$ \\
\hline Unemployed last & $0.146^{\star \star \star}$ & $0.144^{\star \star}$ & $0.146^{\star \star}$ & $0.149^{\star \star}$ & $0.151^{\star \star}$ \\
\hline \multicolumn{6}{|l|}{12 month } \\
\hline Wage & $-0.087^{\star \star \star}$ & $-0.081^{\star \star \star}$ & $-0.078^{\star \star \star}$ & $-0.079^{\star \star \star}$ & $-0.079^{\star \star \star}$ \\
\hline Observations & 1871 & 1504 & 1313 & 1149 & 945 \\
\hline \multicolumn{6}{|c|}{$\begin{array}{l}\text { Note: Average Marginal Effects are computed based on the coefficients of a logit regression with job loss expectations as dependent variable } \\
\text { using only data from } 1991 \text {. Average Marginal effects for later years are then estimated using the values of the control variables in these years } \\
\text { but the coefficients from the logit regression in } 1991 \text { to assess how changes in the distribution of control variables affect the values of average } \\
\text { marginal effects over time when coefficients are held constant. Significance: }{ }^{*} \text { Significant on the } 10 \text { percent level, }{ }^{* *} \text { Significant on the } 5 \text { percent } \\
\text { level, }{ }^{* * * ~ S i g n i f i c a n t ~ o n ~ t h e ~} 1 \text { percent level. }\end{array}$} \\
\hline
\end{tabular}


Table 9: Determinants of Expectations, Unemployment and Accurate Expectations in East Germany without Expected Firm Employment

\begin{tabular}{|c|c|c|c|c|c|c|}
\hline \multirow[t]{2}{*}{ Dependent Variable } & \multicolumn{2}{|c|}{ Job Loss Exp. } & \multicolumn{2}{|c|}{ Actual Unemployment } & \multicolumn{2}{|c|}{ Accurate Expectations } \\
\hline & 1991 & 1999 & 1991 & 1999 & 1991 & 1999 \\
\hline \multicolumn{7}{|l|}{ Change Firm Emp. } \\
\hline \multicolumn{7}{|l|}{ Previous Year } \\
\hline Increased (Reference) & - & - & - & - & - & - \\
\hline Decreased & $0.291^{\star \star \star}$ & $0.107^{\star \star \star}$ & $0.116^{\star \star \star}$ & 0.036 & $-0.153^{\star \star \star}$ & $-0.103^{\star \star}$ \\
\hline Constant & 0.074 & 0.007 & 0.03 & 0.009 & -0.038 & 0.012 \\
\hline Don't Know & 0.083 & $0.221^{\star \star \star}$ & 0.051 & 0.064 & -0.12 & 0.041 \\
\hline \multicolumn{7}{|l|}{ Firm Size } \\
\hline 1 to 20 employees (Reference) & - & - & - & - & - & - \\
\hline 20 to 200 employees & $0.064^{\star}$ & 0.043 & $0.08^{\star \star}$ & 0.001 & -0.009 & 0.057 \\
\hline 200 to 2000 employees & $0.138^{\star \star \star}$ & $0.103^{\star \star \star}$ & $0.106^{\star \star \star}$ & -0.032 & -0.033 & 0.043 \\
\hline More than 2000 & $0.15^{\star \star \star}$ & 0.031 & 0.037 & $-0.1 \star \star \star$ & -0.066 & 0.051 \\
\hline \multicolumn{7}{|l|}{ Industry } \\
\hline Trade, Transport (Reference) & - & - & - & - & - & - \\
\hline Manuf., Agric. Energy & $0.139^{\star \star \star}$ & -0.052 & 0.034 & 0.029 & -0.002 & -0.035 \\
\hline Construction & 0.056 & 0.019 & 0.065 & $0.12^{\star \star}$ & 0.061 & $-0.184^{\star \star \star}$ \\
\hline Serv., Bank, Insur. & 0.016 & -0.049 & -0.059 & 0.024 & 0.069 & -0.035 \\
\hline Male & $-0.08^{\star \star \star}$ & $-0.044^{\star}$ & $-0.066^{\star \star}$ & $-0.064^{\star \star}$ & 0.049 & $0.078^{\star \star}$ \\
\hline Unemployed last & $0.16^{\star \star \star}$ & $0.215^{\star \star \star}$ & $0.325^{\star \star \star}$ & $0.259^{\star \star \star}$ & 0.085 & 0.01 \\
\hline \multicolumn{7}{|l|}{12 month } \\
\hline Wage & $-0.095^{\star \star \star}$ & -0.015 & $-0.092^{\star \star \star}$ & $-0.033^{\star \star}$ & 0.012 & 0.025 \\
\hline Observations & 1871 & 945 & 1871 & 945 & 1871 & 945 \\
\hline
\end{tabular}

Note: Displayed coefficients are average marginal effects from logistic regression. Values for tenure, age, job changes and wage are standardized on a yearly basis. For readability, results for some control variables have been suppressed. The full list of control variables are: gender, education, state of residence, occupation, industry, indicators for the unemployment history, whether the worker lived in a urban or rural area, firm size, how the employment in her firm changed in the last 12 months as well as values for age, age ${ }^{2}$, wages, tenure in the industry and tenure in the firm standardized (by year). Significance: * Significant on the 10 percent level, ** Significant on the 5 percent level, *** Significant on the 1 percent level.

Source: Own calculations based on the GSOEP. 


\section{Imprint}

\section{IAB-Discussion Paper 5|2021}

\section{Publication Date}

9 April 2021

\section{Publisher}

Institute for Employment Research

of the Federal Employment Agency

Regensburger Straße 104

90478 Nürnberg

Germany

\section{All rights reserved}

Reproduction and distribution in any form, also in parts, requires the permission of the IAB

Download

http://doku.iab.de/discussionpapers/2021/dp0521.pdf

All publications in the series "IAB-Discusssion Paper" can be downloaded from

https://www.iab.de/en/publikationen/discussionpaper.aspx

\section{Website}

www.iab.de/en

\section{Corresponding author}

Bernd Fitzenberger

E-Mail bernd.fitzenberger@iab.de 